\title{
Control of Lyme borreliosis and other Ixodes ricinus-borne diseases
}

\author{
Hein Sprong ${ }^{1,4^{*}}$, Tal Azagi ${ }^{1 \dagger}$, Dieuwertje Hoornstra ${ }^{3 \dagger}$, Ard M. Nijhof ${ }^{2}$, Sarah Knorr ${ }^{2}$, M. Ewoud Baarsma ${ }^{3}$ \\ and Joppe W. Hovius ${ }^{3}$
}

\begin{abstract}
Lyme borreliosis (LB) and other Ixodes ricinus-borne diseases (TBDs) are diseases that emerge from interactions of humans and domestic animals with infected ticks in nature. Nature, environmental and health policies at (inter) national and local levels affect the risk, disease burden and costs of TBDs. Knowledge on ticks, their pathogens and the diseases they cause have been increasing, and resulted in the discovery of a diversity of control options, which often are not highly effective on their own. Control strategies involving concerted actions from human and animal health sectors as well as from nature managers have not been formulated, let alone implemented. Control of TBDs asks for a "health in all policies" approach, both at the (inter)national level, but also at local levels. For example, wildlife protection and creating urban green spaces are important for animal and human well-being, but may increase the risk of TBDs. In contrast, culling or fencing out deer decreases the risk for TBDs under specific conditions, but may have adverse effects on biodiversity or may be societally unacceptable. Therefore, in the end, nature and health workers together must carry out tailor-made control options for the control of TBDs for humans and animals, with minimal effects on the environment. In that regard, multidisciplinary approaches in environmental, but also medical settings are needed. To facilitate this, communication and collaboration between experts from different fields, which may include patient representatives, should be promoted.
\end{abstract}

Keywords: Lyme borreliosis, Tick-borne encephalitis, Anaplasmosis, Ixodes ricinus, Transmission cycles, Vaccines, Prevention

\section{Background}

Ixodes ricinus is a hard tick species that transmits pathogens of medical and veterinary importance. It has recently become clear that the bite of $I$. ricinus by itself can also cause meat allergy $[1,2]$. Ixodes ricinus-borne infectious diseases are a considerable health concern in many European countries for several reasons.

First of all, the European Center for Disease Prevention and Control has predicted that the incidence of tick-borne diseases (TBDs) will rise in the near future [3]. Several studies describe a long-lasting increase in the incidences of the two most commonly reported TBDs, namely Lyme borreliosis (LB) and tick-borne

\footnotetext{
* Correspondence: hsprong@gmail.com

${ }^{\dagger}$ Tal Azagi and Dieuwertje Hoornstra contributed equally to this work. ${ }^{1}$ Centre for Zoonoses \& Environmental Microbiology, Centre for Infectious Disease Control, National Institute for Public Health and the Environment, Bilthoven, the Netherlands

${ }^{4}$ Laboratory of Entomology, Wageningen University and Research Centre, Wageningen, the Netherlands

Full list of author information is available at the end of the article
}

encephalitis (TBE) in several European countries [4-9]. Another trend is that human infections and diseases involving other tick-borne pathogens (TBPs), such as Anaplasma phagocytophilum, Borrelia miyamotoi, Neoehrlichia mikurensis, spotted fever rickettsiae and Babesia species, are emerging or being (re)discovered. Indeed, the number of studies describing infections and disease cases involving these agents is accumulating in the literature [10-17]. The severity and incidence of TBDs, other than LB and TBE, is unknown, awareness is low and adequate diagnostic modalities are often lacking in routine settings. Many of these pathogens are also of veterinary relevance, not only for livestock, but also for pet animals [18-21].

Secondly, the reliability of the diagnosis of LB and the efficacy of antibiotic treatments are publicly being questioned, including by some self-proclaimed experts and medical doctors $[22,23]$. The (inter)national guidelines on the clinical diagnosis with recommendations for supporting laboratory diagnosis and treatment appear to 
be a matter of continuous debate [24]. This has led to considerable societal unrest. Furthermore, as I. ricinus is often infected with multiple zoonotic agents, it is still unclear to what extent co-infections are able to affect the course of LB [25]. Doubts and uncertainties about the severity, symptoms, diagnosis and treatment of TBDs are widespread in the media, and give rise to uncertainties and controversies between patients and health providers. This rising concern for TBDs has contributed to the formation of LB interest groups in many European countries, who actively seek public and political awareness, particularly for LB. In the Netherlands, for example, an association for LB patients presented a petition with more than 70,000 signatures of concerned citizens to the parliament for more awareness and research on LB and political attention [26].

Together, these concerns require actions of public and medical health professionals and require solid, evidencebased solutions, to minimize the concerns and disease burden of TBD. This review aims to link the knowledge on I. ricinus and TBDs from different disciplines, in order to formulate possible solutions and knowledge gaps to control ticks and TBDs. An excellent review on the public health concerns and the challenges to control of I. scapularis-borne diseases in the USA has been published [27]. Despite the differences in ecology, epidemiology, environmental and health care systems, there are overlapping research questions which can be tackled together.

\section{Abundance and spread of I. ricinus}

Understanding which factors drive population densities of disease vectors is an important step in assessing disease risk and formulating possible intervention strategies. Ixodes ricinus has a four stage life-cycle, i.e. egg, larva, nymph and adult, requiring only one blood meal during every active stage. The time for I. ricinus to complete its life-cycle varies between three and six years, mostly depending on climate and host availability. Ixodes ricinus employs an ambush strategy for host finding [28], which implies climbing the vegetation, clinging to the tips of stems, and waiting for a vertebrate host. Questing ticks cling to a host animal as the animal passes through vegetation. After feeding for a few days, ticks detach from the host and fall in the litter layer. It takes several months to molt into their next developmental stage, or, in the case of adult females, to lay several thousand eggs and subsequently die. Only a small fraction of the ticks complete the life-cycle: about $10 \%$ of the questing larvae will develop into a questing nymph, and then again between only 1 and $10 \%$ of the nymphs manage to develop into a questing adult.

Although I. ricinus can utilize a multitude of host species, these host species differ considerably in the numbers of ticks they feed, which further differs between the different tick life stages. In forest areas, larvae predominantly feed on rodents, nymphs feed on the highest variety of host, but mostly forest birds and rodents, whereas the key reproduction hosts for ticks are deer [29]. Although annual fluctuations in rodent densities affect the densities of nymphs the following year to some extent, the (local) presence of propagation hosts, mostly deer, is often the key factor for the presence of moderate tick densities in forested areas [30]. Ixodes ricinus spends almost its entire life in the vegetation. Temperature and relative humidity are key requirements for the development, survival and activity of I. ricinus. They are considered to be the principal factors limiting the geographic range of I. ricinus [3133]. More locally, the survival time of ticks also strongly depends on (micro)climatic conditions. The large spatiotemporal fluctuations in the densities of questing ticks within a location is mostly determined by daily and seasonal weather conditions [34]. More generally, the climatic changes over the last decades have probably resulted in an increased length of the annual tick questing season [35], whether that has affected the population sizes of ticks is unknown.

These key requirements imply that $I$. ricinus is mainly found in deciduous woodland containing small mammals and deer, but in some areas with sufficient rainfall, large populations may occur in open habitats such as meadows, dune areas and moorland, where the majority probably feed on livestock [36]. Although very focal and often in low densities, I. ricinus has also been found in green areas in cities, such as parks and gardens $[37,38]$. There, hedgehogs, rather than deer, might act as propagation hosts $[39,40]$.

\section{Policy driven changes in abundance and spread}

Although direct evidence is lacking, the increase in LB and TBE incidence is very likely caused in part by the increase and spread of I. ricinus populations [41]. Tick-suitable areas in Europe are expanding, particularly due to reforestation and other actions to restore and protect nature [35, 42-47]. For example, the protective status of wildlife has resulted in increases in their abundance and spread, particularly of deer populations. Expanding and creating ecological networks across Europe is not only beneficial for wildlife, but also for ectoparasites and their associated pathogens, allowing easier maintenance and spread to new areas. The current policy of some European countries is to create more green spaces in (sub)urban areas to improve human health and well-being, and to mitigate the effects health risks such as heat wave, air pollution and flooding (Committee on Climate Change 2014). It is important to realize, however, that these spaces may also enhance opportunities for contact between humans and I. ricinus, posing risks for acquiring TBDs [38, 48-50]. 


\section{Transmission dynamics of TBDs}

Pathogens can be acquired by ticks while feeding on infected hosts. In suitable tick vectors, TBPs have the ability to persist throughout the molting process to the next instar, a phenomenon called transstadial transmission. The efficiency of vertical transmission, from female tick to her offspring, varies from non-detectable for $B$. burgdorferi (s.l.) and B. microti [51, 52], to $\sim 40 \%$ for $B$. venatorum [53] to close to $100 \%$ for $R$. helvetica [54]. Ixodes ricinus is capable to transmit more than twenty different (potentially) pathogenic parasites, bacteria and viruses via their blood meal to vertebrate hosts (Table 1). Pathogen transmission by ticks requires many often unexplored tick-pathogen interactions, from the migration of these pathogens from the gut to their secretion in tick saliva [55].

Vertebrate hosts can be regarded best as amplifying hosts for TBDs, their prominent role is to produce a sufficient number of newly infected ticks to close the enzootic cycles of pathogens. The infection dynamics of pathogens in vertebrate hosts varies in host range, tissue tropism and infection time. The host range of some pathogens, for example B. lusitaniae and A. phagocytophilum ecotype II, is relatively small with only a few vertebrate species being able to act as amplifying hosts, whereas the host range of others, such as B. afzelii and $A$. phagocytophilum ecotype $\mathrm{I}$, is much broader. Tissue tropism varies from skin (B. afzelii), to blood (Babesia species), immune cells (A. phagocytophilum, N. mikurensis), endothelium ( $R$. helvetica) and even to the central nervous system (TBEV, B. garinii). Sometimes, adequate immune responses are developed, for example against $B$. miyamotoi and TBEV, giving rise to short-term, limited infections. Other pathogens, such as B. burgdorferi (s.l.), A. phagocytophilum and probably also several Babesia species too can evade the immune system and cause chronic, long-lasting infections. Infections with B. garinii appear to be latent in thrushes (Turdus iliacus) for several months, but can then be reactivated by physiological cues [56]. Recurrent bacteremia also occurs in sheep, which remain infected persistently with $A$. phagocytophilum [57].

Transmission dynamics can also be affected at the (vertebrate) community levels via many, often poorly understood, mechanisms. For example, most vertebrates often are simultaneously or sequentially infected with multiple pathogens. Patterns of (co-)infection arise because infection by one microorganism affects susceptibility to others or due to inherent differences between hosts [58]. Another example is the dilution effect hypothesis, where diluting the abundance of transmission-competent hosts with non-competent hosts will reduce the probability of ticks feeding on transmission-competent hosts and consequently decreases the infection prevalence of pathogens in ticks [59]. This mechanism probably applies only in certain circumstances for a few TBPs, and even less often if considering abundance rather than prevalence of infected ticks [60]. Recently, we showed that mesocarnivores can lower the number of ticks feeding on reservoir-competent hosts, which implies that changes in predator abundance may have cascading effects on tick-borne disease risk [61].

Transmission dynamics can also be affected by weather and climatic conditions. The seasonal synchrony of larval and nymphal stages is an important driver of nonsystemic transmission of TBEV via co-feeding of infected nymphs with uninfected larvae. This synchrony in tick activity and feeding, in turn, is affected by temperature patterns, in particular autumn cooling and spring warming $[62,63]$. Climate change might therefore not only affect the distribution of ticks themselves, but also the distribution and nymphal infection rate of TBEV, and maybe also of other TBPs [41, 64].

These infection dynamics are important drivers for the abundance and spread of infected ticks, and therefore have major clinical implications, implications on the incidence, but also on the risk management and control of the associated diseases. For example, the geographical distribution of TBEV is multifocal [63] with relatively low infection rates, whereas Lyme spirochetes are more widespread with relatively high infection rates in $I$. ricinus [65]. Five genospecies of B. burgdorferi (s.l.) are commonly associated with LB in Europe: B. afzelii, B. garinii, B. burgdorferi (sensu stricto), B. spielmanii and $B$. bavariensis [23]. Borrelia afzelii is predominantly involved in cutaneous manifestations, such as erythema migrans (EM) and acrodermatitis chronica atrophicans (ACA), B. garinii and $B$. bavariensis in neuroborreliosis (LNB), and B. burgdorferi in Lyme arthritis (LA) [23, 66]. The incidence of the different manifestations of LB can be partially explained by their pathogenicity and by the relative occurrences of different genospecies in questing ticks [34]. Specific associations have also been found between vertebrates and Borrelia genospecies. For example, rodents and voles appear to contribute most to the transmission cycle of $B$. afzelii, whereas thrushes contribute most to the $B$. garinii and B. valaisiana cycles [29]. It is to be expected that local abundances of these animals in tick suitable recreational areas determine the risk of acquiring the specific disease manifestations [38, 45].

\section{Epidemiology of TBDs}

Measuring incidences and cost of illness (humans) or production loss (livestock) can guide decision-makers to prioritize health policies and initiate cost-effective actions to control diseases with the highest economic or societal impact [67]. As TBE is notifiable in many European countries, incidences and sometimes also cost of illness have been estimated [68]. This information has enabled the 
Table 1 Pathogens detected in, or transmitted by, I. ricinus. Pathogens are defined here as microorganisms which have been implicated in disease, because of evidence of infection in patients. Some pathogens have only caused disease in immune compromised cases. For most pathogens the Koch's postulates have not been fulfilled and solid epidemiological evidence is lacking too [217]. Some pathogens, particularly Bartonella, Francisella and Coxiella, have other main modes of transmission. Transmission of Hepatozoon spp. by I. ricinus is not proven, but the infection of animals with Hepatozoon spp. usually involves the digestion of infected ticks. Finally, human infections of TBEV have also occurred through ingestion of contaminated, unpasteurized milk products [218], and other tick-borne pathogens have been transmitted via blood transfusion

\begin{tabular}{|c|c|c|c|}
\hline Microorganism & Variants & Disease & Reference \\
\hline \multirow[t]{10}{*}{ Borrelia burgdorferi (s.l.) } & B. afzelii & Human & \multirow[t]{10}{*}[23,91,219]{} \\
\hline & B. garinii & Human & \\
\hline & B. burgdorferi (s.s.) & Human/ animal & \\
\hline & B. spielmanii & Human & \\
\hline & B. valaisiana & Human & \\
\hline & B. bavariensis & Human & \\
\hline & B. bissetti & Human & \\
\hline & B. finlandensis & - & \\
\hline & B. lusitaniae & Human & \\
\hline & B. turdi & - & \\
\hline \multirow[t]{5}{*}{ Babesia species } & B. venatorum & Human/animal & \multirow[t]{5}{*}{ [220-222] } \\
\hline & B. divergens & Human/ animal & \\
\hline & B. microti & Human & \\
\hline & B. capreoli & Animal & \\
\hline & B. odocoilei(-like) & - & \\
\hline \multirow[t]{2}{*}{ Spotted fever rickettsia } & R. helvetica & Human & \multirow[t]{2}{*}{ [223] } \\
\hline & R. monacensis & Human & \\
\hline \multirow[t]{2}{*}{ Anaplasma phagocytophilum } & Ecotype I & Human /animal & \multirow[t]{2}{*}{ [224] } \\
\hline & Ecotype II & - & \\
\hline \multirow[t]{2}{*}{ Borrelia miyamotoi } & Russian & Human & \multirow[t]{2}{*}{ [17] } \\
\hline & European & Human & \\
\hline Neoehrlichia mikurensis & & Human/animal & {$[225,226]$} \\
\hline Spiroplasma ixodetes & & Human/animal & {$[227,228]$} \\
\hline \multirow[t]{3}{*}{ Orbivirus } & Kemerovo virus & Human & \multirow[t]{3}{*}{ [229] } \\
\hline & Lipovnik virus & Human & \\
\hline & Tribeč virus & Human & \\
\hline \multirow[t]{2}{*}{ Flaviviruses } & Tick-borne encephalitis virus & Human & \multirow[t]{2}{*}[18,230,231]{} \\
\hline & Louping ill virus & Animal/ human & \\
\hline Nairovirus & Grotenhout virus & - & [232] \\
\hline Coltivirus & Eyach virus & Human & {$[230,233]$} \\
\hline Phlebovirus viruses & Uukuniemi(-like) virus & - & [234] \\
\hline Midichloria midichondria & & - & [235] \\
\hline Hepatozoon species & & - & [236] \\
\hline Coxiella burnetti & & Human/animal & [237] \\
\hline Francisella tularensis & F. tularensis holarctica & Human/animal & {$[238,239]$} \\
\hline Bartonella species & & Human & [240] \\
\hline
\end{tabular}

calculation of the cost-effectiveness of vaccination strategies against TBE in several countries [69], which further aided the formulation of various strategies to control TBE, from creating awareness alone to incidence-, travel- or profession-based vaccination advises to mass-vaccination campaigns $[9,70]$. 
The epidemiology of LB is more complex. In most European countries LB is not notifiable and incidence estimates are often based on passive reporting laboratory surveillance or on incidental, systematic investigations $[71,72]$. Early stages of LB are underreported in laboratory surveillances, because most cases are serologically negative at presentation. Furthermore, laboratory testing at that stage is often not required, hence not recommended by guidelines, for the diagnosis of EM. Most importantly, the clinical manifestations of LB differ enormously in incidence and disease burden. In the Netherlands, 95\% of the LB cases are EM, 2\% LNB, 2\% LA, $0.9 \%$ ACA, $0.4 \%$ borrelial lymphocytoma, $0.1 \%$ Lyme carditis and $0.1 \%$ had ocular manifestations [71]. In Germany, comparable proportions were observed [73]. A recent study estimated the total disease burden of LB for the Netherlands. Although 91\% of the LB cases had EM, it only constitutes $\sim 6 \%$ of the disease burden, whereas the $\sim 5 \%$ cases which displayed persisting symptoms attributed to LB accounted for almost $90 \%$ of the disease burden [74]. Thus, controlling the incidence of patients with persisting symptoms attributed to LB, will have the highest impact on reducing disease burden, but hardly on the disease incidence.

Only a few studies have investigated the incidence of other TBDs transmitted by I. ricinus, such as anaplasmosis and babesiosis, in Europe [75]. For example, a seroepidemiological study estimated between 10 and $40 \mathrm{hu}-$ man anaplasmosis cases in Belgium per year $[11,76]$. Human cases of other TBDs are being reported in the literature, mostly as case studies or series. In contrast, the exposure through bites of infected ticks in the general population and in risk groups such as forest workers is high. Based on molecular evidence alone, the probability of infection with a TBP other than Lyme spirochetes after a tick bite is roughly $2.4 \%$ [12]. Similarly, among patients with EM, the probability of a co-infection with another TBP is approximately 3\% [12]. How often these infections cause disease or to what extent co-infections affect the course of LB needs further investigation. Infections with TBDs in humans is supported by many serological studies where antibody titers against for example A. phagocytophilum have been found in a few percent of human populations [77-79]. Nonetheless, the incidence and severity of the medical problems caused by these TBPs in many, if not all, European countries are unknown. One of the reasons for that is that current diagnostic tools for many of the TBDs are non-existing, of questionable quality, or poorly validated in the European setting. As a consequence, the awareness of other TBDs among physicians and the public is generally low. Therefore, to gain more knowledge on the incidence and nature of TBDs it is imperative to improve laboratory diagnostic tests and awareness.
Domestic animals are more prone to exposure to ticks than humans, as they generally spend more time outdoors, are in closer proximity to the ground and vegetation, and have coats that facilitate tick attachment. Since none of the TBDs associated with I. ricinus are notifiable in Europe, official information on TBD incidence in animals is not available. One exception is Q-fever caused by Coxiella burnetii, but the role of ticks in the epidemiology of the disease is considered to be negligible [80]. Most reports concern case descriptions, seroprevalence studies or molecular surveys looking at the occurrence of pathogens in ticks collected from the vegetation or animals, which says little about the actual incidence of clinical disease in animals.

\section{Clinical aspects of TBDs: clinical presentation, diagnostics and treatment Clinical presentation of LB and TBE}

LB is divided in three partially overlapping stages, reflecting the duration of the infection and the severity of the disease [23, 81]. The first stage is characterized by the hallmark EM, an erythematous expanding skin lesion at the site of the tick-bite (Fig. 1), usually occurring 1-2 weeks after the tick-bite. When left untreated or unnoticed the infection can disseminate and cause early disseminated and eventually late disseminated LB, the second and third stage respectively [81]. The characteristic manifestations of early disseminated LB include other skin manifestations, such as lymphocytoma and multiple EM, carditis, oligoarthritis and neurological symptoms, such as meningo-(poly)radiculitis (Bannwarth syndrome) with or without cranial nerve involvement [82], amongst other rare manifestations. The central nervous system or the joints can also be affected in late disseminated disease, but the hallmark clinical manifestation of late LB is ACA [83].

Apart from these clear-cut manifestations, there are patients with non-characteristic complaints such as myalgia, arthralgia, fatigue, which are sometimes attributed to LB. These complaints are often long-lasting and can even be debilitating. The constellation of these symptoms is sometimes referred to as chronic Lyme, however this term seems to be an umbrella name for a variety of diseases and syndromes [22, 84]. Examples thereof include late disseminated LB, post-treatment LB syndrome (a post-infectious syndrome), a persisting $B$. burgdorferi (s.l.) infection after antibiotic treatment, or one of many other diagnoses misattributed to LB [85]. How to define "chronic Lyme" is more than a semantic discussion as a proper diagnosis [84], i.e. the identification of the nature and cause of an illness, greatly determines the care and cure of patients [85], and could lower the disease burden and medical costs.

Exposure to Lyme spirochetes in animals in Europe is common, with reported seroprevalences in Europe in 

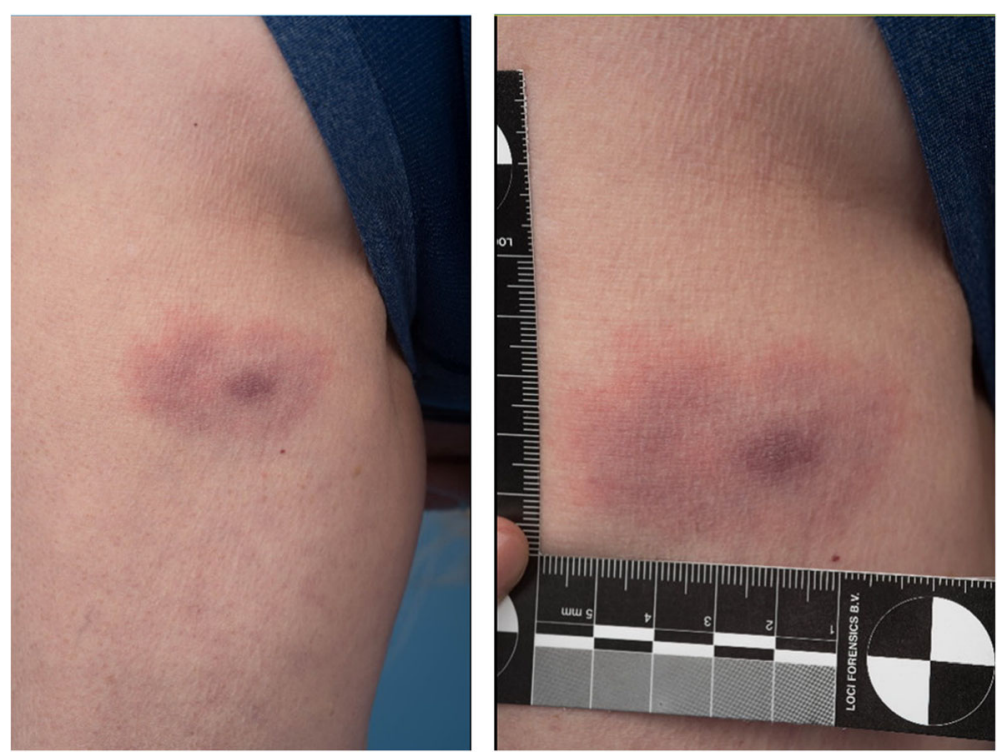

Fig. 1 Clinical representation of an EM, the most common manifestation of LB. A culture-proven EM (diameter $\sim 6 \mathrm{~cm}$ ) on the leg of a 62 -year-old female. This patient presented with this slowly expanding macula with very faint central clearing as the only symptom. There was no known tick bite prior to the development of the lesion.

healthy dog populations ranging from $0.3 \%$ in southern Italy [86] to $26 \%$ in Serbia [87] and $7 \%$ in horses from in Italy [88] to $30 \%$ in France [89], but clinical disease with a conclusive LB diagnosis is rare. Clinical LB caused by B. burgdorferi (s.s.) has nonetheless been reported in dogs, horses and cats [90-95]. A broad spectrum of clinical signs has been associated to Borrelia infections in animals, including fever, lethargy, weight loss, (shifting) lameness, ataxia, uveitis, polyarthritis, glomerulopathy and neuritis [96-98]. This variation might to some extent be the result of unapparent co-infections with other pathogens, such as A. phagocytophilum $[99,100]$.

Ixodes ricinus ticks transmit the European variant of TBEV [101]. Although the majority of human infections are asymptomatic, the first symptoms are displayed between 228 days (median $=8$ ) after a tick bite [102, 103]. Infections with the European TBEV usually display a typical biphasic course with a viremic phase of 2-10 days and a neurological phase of $1-21$ days, separated by a period (median $=7$ days) without symptoms [104]. In the first phase the most common symptoms are fever, fatigue and headaches [103]. After a temporary recovery, neurological symptoms appear in the second phase, ranging from mild meningitis to severe meningoencephalomyelitis [103]. Although TBEV-EU mortality is relatively low $(1-2 \%)$, neurological sequelae, which can greatly affect the quality of life, often occur [105]. TBEV may also affect dogs and result in fever, change in behavior and various neurological symptoms (reviewed in [106]). A variant of the TBEV, Louping Ill virus causes acute encephalomyelitis, resulting in severe illness and death in livestock, especially sheep and red grouse [18].

\section{Clinical presentation of other TBDs}

The clinical spectrum of human granulocytic anaplasmosis ranges from subclinical and self-limiting to subacute, chronic or severe in the immunocompromised [107]. The incubation period is $1-2$ weeks, after which non-characteristic symptoms (e.g. fever, flu-like symptoms) arise, accompanied by nausea, vomitus, abdominal pain and arthralgia in approximately one-third of the patients. A skin rash or neurological symptoms are less frequently observed, and the estimated fatality rate is less than 1\% [108-112]. Animal species that may be affected by $A$. phagocytophilum include dogs, cattle, horses and sheep and clinical signs vary in severity but are usually non-specific such as fever, lethargy and anorexia [113]. To date, there are dozens of case reports of human neoehrlichiosis, the disease caused by N. mikurensis, describing acute and chronic infections characterized by fever, headache, nausea, arthralgia, haemorrhages and weight loss [16]. Borrelia miyamotoi causes hard tick-borne relapsing fever (HTBRF). The onset of symptoms starts approximately two weeks after a tick-bite with a sudden onset of high fever with signs of septicaemia accompanied by headache, myalgia, arthralgia, and coughing or even gastrointestinal symptoms. The relapsing fever episodes typically last three days, divided by seven relatively healthy days, although for HTBRF the typical relapsing fever pattern is not that often observed [114]. The general trend of the course of the disease is subsiding and self-limiting, but in rare cases, i.e. in highly immunocompromised individuals, the disease appears to be neuro-invasive [114-118]. The two spotted 
fever rickettsias transmitted by $I$. ricinus are $R$. helvetica and $R$. monacensis. Their infections may cause vasculitis with fever, headache, myalgia and local lymphadenopathy. An inoculation eschar and generalized maculopapular rash, which are pathognomic for other spotted fever rickettsiosis, are rarely described for these genospecies $[115,119,120]$. The pathogenicity of $R$. helvetica is only partly established by several case series and reports in Europe [121-126]. Rickettsia monacensis infection is even less defined, although culture, molecular and serological evidence of human exposure has been reported [127-129].

In Europe, human babesiosis is caused by B. microti, $B$. divergens and B. venatorum [12, 130-132]. All Babesia species infect erythrocytes and cause haemolysis, leading to the clinical manifestations of fever, anaemia, jaundice, haemoglobinuria and potentially also renal insufficiency. Over 40 human babesiosis cases have been reported in Europe, mostly in asplenic patients. Other risk factors are immunosuppression, depletion of mature B-cells and old age [21]. Judging from the discrepancy between case reports and seroprevalence, an asymptomatic and/or self-limiting course is common [133]. Although serious infection appears to be uncommon, when acquired, the disease has a mortality rate of $42 \%$ in B. divergens and 5\% in B. microti [134]. Babesia divergens is the causal agent of bovine babesiosis in Europe. The clinical picture is similar to that seen in humans, with a bimodal seasonal occurrence of the disease that is associated with I. ricinus activity. In cattle, an inverse age resistance phenomenon is present in which calves up to the age of 9-12 months are susceptible for infection, but resistant to disease [21].

Human infections with multiple TBDs and even with non-tick borne pathogens have been described [135, 136]. Co-infections have been shown to affect the course of LB causing a longer and more disabling course of disease [137-142]. Although co-infections in ticks are the rule rather than the exception [25,34], the opposite is probably true in humans: co-infections seem to occur only occasionally $[129,143-146]$. Our recent findings indicate that among patients with EM the probability of a co-infection with second TBP is merely 3\% [12]. To date, there is no convincing evidence that infection with any other TBP or any other infectious agent, is associated with chronic Lyme $[147,148]$.

\section{Diagnosis of $\mathrm{LB}$}

In diagnosing LB, the foremost tool for a physician is a thorough history and physical examination. An EM is considered a clinical diagnosis and additional laboratory testing for EM is discouraged [82]. For many other disseminated forms of LB, laboratory work-up, including a search for alternative explanations, may serve to aid the physician. Serology is the current standard as it has good diagnostic parameters with a sensitivity and specificity of more than $90-95 \%$ in LB patients with late (disseminated) manifestations [149]. Serology has some disadvantages. First, the sensitivity is low in early stages of LB, approximately 50\% [149], which may lead to a wrong or delayed diagnosis. Secondly, approximately $5 \%$ of the general population - and even higher depending on the age, geographical region and the population examined - have antibodies against Lyme spirochetes, while not having active LB [150]. Thus, serology cannot always differentiate well between a past and a current Borrelia infection [151-153]. Additional tests include PCR or culture, which are only recommended for specific manifestations and specific tissues or fluids: on synovial fluid/tissue in the case of LA, on a skin biopsy in the case of an ACA or in some specific cases of LNB on cerebrospinal fluid (CSF) [154, 155]. For LNB, other laboratory tests are available, such as leukocyte count, intrathecal antibody production, or intrathecal CXCL-13 concentration, to support the presence of an infection in the central nervous system or other inflammatory conditions [156].

The diagnosis of any form of chronic Lyme is far more complicated. Some of these patients may benefit from (additional) antibiotic treatment, while others may be better helped with other forms of treatment or rehabilitation. A laboratory test that is able to adequately differentiate between a past and active Borrelia infection is desired for these patients. It has been hypothesized that cellular tests have this ability. Several of these tests are already commercially available, but their accuracy has not been adequately determined [157-160] and, therefore, warrants more research before they can be used in clinical practice [159]. In addition, there are many alternative methods, which are said to test for LB, but sound evidence for these methods (e.g. as dark field microscopy directly on blood, VEGA-test or bio-resonance) is lacking [161].

When deciding to test for a given condition, whether it be LB or any other disease, it is important not to only take into consideration what the technical performance of a test is, but to also consider the pre-test probability that the patient has the disease [155]. When the pre-test probability of LB is low, then - taking into account the current diagnostic parameters of serological tests and the incidence of IgG-seropositivity in the general population - the added value of testing is limited. Furthermore, the various LB manifestations, the pre-test probabilities as well as the population under study and their expectations vary greatly between primary, secondary, and tertiary care. This might also affect recommendations for the use of Borrelia serology in current guidelines and requires further investigation. In that regard, although not recommended in most guidelines, 
it could be argued that testing for LB in patients with longer-lasting symptoms with a low pre-test probability in the primary care setting, could actually be helpful. In this situation, a negative test result would make an LB manifestation extremely unlikely, whereas a positive test result would require further investigation, e.g. referral to secondary or tertiary care center. Nevertheless, in some situations testing for LB is discouraged altogether, specifically when the patient is clinically diagnosed with an EM.

The non-specific clinical picture, together with a high seroprevalence, also complicate the diagnosis of LB in animals. The combination of a history to tick exposure within an endemic region, clinical signs consistent with $\mathrm{LB}$, a positive test result, exclusion of differential diagnoses and response to treatment are required for a presumptive LB diagnosis in animals [162].

\section{Diagnosis of TBE and other TBDs}

TBEV infection is associated with general non-specific infectious biochemical and blood count results. CSF analysis usually shows pleocytosis with polymorphonuclear cells early, and mononuclear cells late, in the disease development [163]. Serology can be performed on both liquor and serum by IgM/IgG ELISA, which is the most common diagnostic method for TBEVinfection in dogs as well [106]. A four-fold rise in TBEVspecific antibodies in liquor or serum confirm the diagnosis. A neutralization assay is recommended in flavivirus endemic regions to avoid a false positive result [104, 164]. Imaging of the brain and/or myelum may result in focal abnormalities; however it does not contribute greatly to the diagnosis [163].

Diagnosis of other TBDs is based on the assembly of specific clinical characteristics, laboratory findings together with diagnostic tools in a setting of relevant epidemiological exposure. The main non-specific laboratory findings associated with other TBDs are general parameters found in infection, such as elevated inflammation parameters (C-reactive protein, erythrocyte sedimentation rate), leukopenia or leucocytosis, thrombocytopenia and anaemia, with or without elevated liver enzymes or kidney dysfunction. Especially in A. phagocytophilum and N. mikurensis infection, leukopenia is observed due to leukocyte infection [108, 165]. Babesia spp. can cause a distinct haemolytic anaemia due to erythrocyte infection with accompanying elevated bilirubin, reticulocytosis and decreased haptoglobin [166]. Thrombocytopenia appears to be most pronounced in anaplasmosis, babesiosis and HTBRF. In the rare severe cases of anaplasmosis and HTBRF with involvement of the central nervous system, the CSF can reveal pleocytosis [167, 168]. For some TBDs, there are additional, more specific, tests available, such as a buffy coat examination for $A$. phagocytophilum or peripheral blood smear with Giemsa staining in A. phagocytophilum and Babesia spp. to look for respectively morulae or merozoites by microscopy $[169,170]$.

Most additional targeted diagnostic tests in TBDs are either in the experimental phase or not widely validated (molecular tests), based on cross-reactivity between other species (serology), time-consuming, or difficult to perform and requiring a high level of expertise (cultures) [171173]. In general, the sensitivity of available molecular tests for all these TBDs is high in the first week of disease and rapidly decreases over time, and after proper treatment. Therefore, a positive PCR result is helpful, but a negative result does not rule out the diagnosis. As an exception to the rule, Babesia spp. can be detected up to months to years after (un)treated infection $[174,175]$.

For most TBPs, there are no standardized antigens, or well-defined consensus as to what thresholds constitute a significant antibody titer. As a rule of thumb, serological tests are usually required to show a four-fold rise in antibody titer in convalescent sera. It should be noted that the onset of symptoms sometimes precedes the rise in antibody titer. In addition, because antibodies may persist beyond the clearance of infection, it can be difficult to distinguish between a past, recent or current infection [21, 169, 176]. For A. phagocytophilum, Babesia and Rickettsia spp. indirect fluorescent antibody tests are available, yet they make use of other strains or even genospecies than the ones found in Europe, with the exception of B. microti [166, 171, 177, 178]. Serological tests for $B$. miyamotoi are in the experimental phase and based on specific antigens (glycerophosphodiester phosphodiesterase (GlpQ) and more recently also variable major proteins (Vmps) identified in the available different isolates from Asia and the USA [179, 180]. These assays do not discriminate between the different relapsing fever Borrelia genospecies. There is no widely available and established serological test for the diagnosis of N. mikurensis infection.

\section{Treatment of TBDs}

LB is treated with antibiotics. The prognosis, especially when treated early in the course of the disease is good, although rarely antibiotic failure can occur. In contrast, persisting symptoms can be observed in approximately $5-20 \%$ of LB patients despite recommended antibiotic treatment [181, 182]. Therefore, this condition has been referred to as post-treatment LB [169]. It has been shown in multiple placebo controlled randomized trials that prolonged antibiotic treatment is not effective in treating these non-specific yet disabling and long-lasting symptoms [183-187]. LB in animals is also treated with antibiotics, usually with doxycycline given per os at $10 \mathrm{mg} / \mathrm{kg}$ every 12 or $24 \mathrm{~h}$ for a period of one month [162, 188]. In horses, the intravenous administration of oxytetracycline 
( $5 \mathrm{mg} / \mathrm{kg} /$ day) was more effective in clearing experimentally induced Borrelia infections than doxycycline treatment [189].

There is no causal treatment for TBEV. Treatment consists of supportive care and there is no evidence that steroids or immunoglobulins are beneficial [104]. Asymptomatic or subclinical infection frequently occurs for all of the other TBDs and thus infection does not necessarily require treatment. However, when symptomatic, treatment is, or may be, warranted. The large group of intracellular other TBDs, such as $A$. phagocytophilum, $N$. mikurensis and spotted fever rickettsia, as well as $B$. miyamotoi are all susceptible to doxycycline, which is the drug of choice $[116,169,173,190]$ for adults. For younger children, pregnant women and when the central nervous system is affected, specific alternatives exist. Therefore, in countries where doxycycline is recommended as the first line treatment for LB, these pathogens would be concomitantly treated. In countries where betalactams are the drug of first choice for LB, clinicians should have a higher level of suspicion for other TBDs, since these are likely not co-treated as such. Moreover, babesiosis requires a different treatment, consisting of azitromycine and atovaquone or clindamycine and quinine depending on the severity of the disease [169]. Cattle suffering from babesiosis are treated with imidocarb diproprionate. In Africa, diminazene aceturate is frequently used to treat bovine babesiosis caused by B. bovis or B. bigemina, but this product is not available in Europe [21].

\section{Control of LB and other I. ricinus-borne diseases}

Knowledge on $I$. ricinus, its associated pathogens and the diseases they cause have been increasing in many fields and many approaches to control or prevent TBDs have been investigated and proposed (Table 2). Excellent reviews and even (hand)books on this topic are available [191-195].

\section{Personal preventive actions}

Control of $I$. ricinus-borne diseases primarily consist of the promotion of personal preventive actions for the public and for risk groups, such as forest workers, by providing information and education. Such actions include avoiding high-risk habitats, wearing protective clothing, application of repellents, prompt removal of attached ticks, and seeking medical advice when developing symptoms (e.g. fever, skin rash) or another illness in weeks to months after a tick bite. Personal protective measures have poor rates of compliance and their effectiveness has been difficult to demonstrate in terms of reducing disease cases [196, 197]. For example, providing information and education has not resulted in a decline

Table 2 Present and potential measures ${ }^{a}$ to control TBDs. This table is modified from Eisen \& Gray [241]. There is not a single method that effectively controls all TBDs. National and local strategies, which combine several methods probably work best [191, 192]. Anti-tick vaccines blocking pathogen transmission in humans and domestic animals might encompass the silver bullet to control TBDs. Hygiene measures ${ }^{\mathrm{b}}$ involve checking for tick bites, prompt removal, and most importantly, seek medical advice when developing symptoms (e.g. fever, skin rash) or illness in weeks to months after a tick bite

\begin{tabular}{|c|c|c|c|c|c|}
\hline Personal & Domestic animal & Residential & Vegetation & Fauna & Medical \\
\hline Avoid tick habitats & Avoid tick habitats & $\begin{array}{l}\text { Xeriscaping/ } \\
\text { Hardscaping }\end{array}$ & Awareness for visitors & & $\begin{array}{l}\text { Increase awareness and } \\
\text { knowledge of medical } \\
\text { doctors }\end{array}$ \\
\hline Protective clothing & $\begin{array}{l}\text { Treatments with } \\
\text { topical or systematic } \\
\text { acaricides }\end{array}$ & $\begin{array}{l}\text { Keep grass short, } \\
\text { remove weeds, remove } \\
\text { leaf litter and brush }\end{array}$ & $\begin{array}{l}\text { Reduce tick abundance } \\
\text { on sites with high } \\
\text { recreational activities }\end{array}$ & Deer fencing & $\begin{array}{l}\text { Technical improvement of } \\
\text { laboratory tests }\end{array}$ \\
\hline Repellents & Hygiene measures ${ }^{b}$ & $\begin{array}{l}\text { Remove harborages/ } \\
\text { food for rodents and } \\
\text { insectivores }\end{array}$ & $\begin{array}{l}\text { Avoidance tick } \\
\text { habitats/ directing } \\
\text { visitor flows }\end{array}$ & Deer removal & $\begin{array}{l}\text { Improvement of diagnostic/ } \\
\text { clinical pathways }\end{array}$ \\
\hline $\begin{array}{l}\text { Acaricide-impregnated } \\
\text { clothing }\end{array}$ & & $\begin{array}{l}\text { Fencing to exclude } \\
\text { wildlife }\end{array}$ & $\begin{array}{l}\text { Mowing/extensive } \\
\text { grazing of paths and } \\
\text { recreational sites }\end{array}$ & $\begin{array}{l}\text { Topical acaricide } \\
\text { for propagation } \\
\text { hosts (deer) }\end{array}$ & $\begin{array}{l}\text { Improve cure and care of } \\
\text { patients with late LB and } \\
\text { persisting complaints }\end{array}$ \\
\hline Hygiene measures ${ }^{\mathrm{b}}$ & & $\begin{array}{l}\text { Move play/rest } \\
\text { structures to low } \\
\text { risk areas }\end{array}$ & $\begin{array}{l}\text { Create open habitats } \\
\text { rather than woodlands }\end{array}$ & Sheep mopping & $\begin{array}{l}\text { Prophylactic antibiotic } \\
\text { treatment after a tick bite }\end{array}$ \\
\hline $\begin{array}{l}\text { Control ticks on } \\
\text { dogs/ cats and in gardens }\end{array}$ & & $\begin{array}{l}\text { Chemical/fungal } \\
\text { acaricides }\end{array}$ & & $\begin{array}{l}\text { Topical } \\
\text { acaricide/antibiotics } \\
\text { for rodents }\end{array}$ & \\
\hline sTBE vaccine & TBE vaccine & & & $\begin{array}{l}\text { Oral } L B \text { vaccine } \\
\text { for rodents }{ }^{a}\end{array}$ & \\
\hline$L B$ vaccine ${ }^{a}$ & LB vaccine & & & $\begin{array}{l}\text { Oral tick growth } \\
\text { regulator/acaricide }\end{array}$ & \\
\hline Tick vaccine ${ }^{a}$ & Tick vaccine ${ }^{a}$ & & & Tick vaccine ${ }^{a}$ & \\
\hline
\end{tabular}


in the incidence of LB in the Netherlands, not even after intensified efforts since 2003 [7].

\section{Environmental-based approaches}

Environmental-based approaches mostly rely on reduction of tick suitable habitats, the disruption of the tick life-cycle or interference with pathogen transmission. A major advantage of environmental-based control options is that most of them can readily be applied in various practical situations, as they involve existing nature management options, such as mowing, grazing or fencing [195]. Furthermore, controlling tick abundance or tick exposure reduces the risk of acquiring any TBD for both humans and domestic animals. So far, there has been little interest in Europe in environmentally-based preventive measures. Large-scale and long-term spraying with acaricides was carried out in Russia during the 1970s and 1980s in an attempt to control I. persulcatus, the main vector of the TBEV [198]. The widespread application of acaricides has been publicly criticized and has become socially undesirable, because of their detrimental effects on the ecosystem and biodiversity [191, 199]. Unlike in the USA, only a limited number of studies exploring environmental-based methods to control ticks have been conducted in Europe [30, 195, 200-202]. A wide range of acaricidal products in various formulations, which are effective against I. ricinus, is being used for tick control on domestic animals [203].

\section{Health in All Policies}

Most, if not all, of the available environmentally-based preventive and control measures suffer from the fact that they are not highly effective on their own [192]. Probably, long-term implementation of control strategies, i.e. the integrated use of two or more control measures, are necessary to effectively reduce disease risk. Only a few studies on the effectiveness of control strategies have been carried out in the USA, but not in Europe [192]. The successful implementation of environmentally-based preventive and control measures requires involvement of stakeholders from both nature management and human (and animal) health ('One Health'). Of key importance is that the environmental control options for TBDs are put into the context of other aims and ambitions, such as nature conservation, ecosystem services or heat mitigation in urban areas. Indeed, sectors involved in nature management and environmental planning are often more familiar with a so-called 'Health in All Policies' approach. The 'Health in All Policies' approach integrates and articulates many health considerations, far broader than infectious diseases alone, into policymaking across sectors. A future challenge is to integrate the risk of TBDs, but also of wildlife- and other vector-borne diseases, into the 'Health in All Policies' in local nature organizations, such as
Municipal Health Services and nature owners, but also governmental institutions and (inter)national organizations responsible for nature and health.

\section{Healthcare actions}

More and better awareness of the epidemiology, clinical presentation and course of the various TBDs amongst physicians could raise a suspicion on these diseases in endemic regions. For example, the communication with health professionals on the presence of $B$. miyamotoi and TBEV in questing ticks in the Netherlands has resulted in the identification of the first cases of HTBRF and TBE [70, 168]. Clearly, there is room for the improvement of laboratory tests for the diagnosis of LB and especially other TBDs. Both direct (antigen tests, cultivation or molecular tests) and indirect tests (serology or cellular tests) could greatly aid in establishing the diagnosis. Rather than making one guideline for each tick-borne disease separately, it might be more advantageous to have one guideline for all TBDs for primary care centers with clear consensus on diagnostic testing and referral to secondary and tertiary care centers. Specialized guidelines for secondary and tertiary care centers can aid the diagnosis and treatment for more severe manifestations of LB, but also and for all variants of chronic Lyme. Finally, better knowledge on the course of the various diseases after treatment could prevent overdiagnosis and retreatment.

\section{Vaccination}

Where the risk of infection is high or the resulting disease severe, vaccines may be the most efficient and costeffective means of prevention and control [204]. TBE is well under control in Austria because of mass vaccination programs. The available TBE vaccines have an effectiveness of $\sim 98 \%$. With a vaccination rate in the population of $85 \%$, it is estimated that more than 4000 severe cases of TBE were prevented in Austria between 2000 and 2011 [205]. Remarkably, the vaccination coverage in many central and eastern European countries is low [206], despite predictions that TBE vaccination programs in central and eastern Europe can be cost-effective [207]. A vaccine protecting against LB is currently unavailable in Europe, but a potential vaccine has recently been tested in a Phase I/II trial [208, 209], and another LB vaccine is being developed for the European market as well [210]. Based on the experiences with a previous Lyme vaccine that was on the American market, with an effectivity between $62 \%$ and $85 \%$, it remains to be seen whether a Lyme vaccine will be widely accepted and used, or only cost-effective for high risk groups [211, 212]. Ideally, one would like to have a single vaccine for humans, protecting against multiple TBDs [213]. Anti-tick vaccines targeting other tick species already exist and are being used in the veterinary field. 
The strategy behind these vaccines is to locally control Rhipicephalus (Boophilus) tick species, and act as a safe and environmentally friendly alternative to acaricides $[214,215]$. Application of anti-tick vaccines was shown to dramatically decrease the incidence of bovine babesiosis [216]. Whether anti-tick vaccines can also be used to (locally) eradicate I. ricinus populations and prevent human TBDs is difficult to predict due to its very large host range, yet is a topic of investigation [213].

\section{Conclusion}

Unfortunately, there is no silver bullet to control TBDs yet. In order to effectively control TBDs, "health" should be considered in a broader context, involving ecosystems, the environment, wildlife, animals and also curative and public health and policymaking. This implies a multidisciplinary approach and asks for international collaborations throughout Europe, but also multidisciplinary collaborations and approaches at local levels. Patient representatives or patient advocacy groups are part of such a multidisciplinary approach. In our experience, patients and researchers often have shared goals and convictions, yet comprehensive collaboration in the field of LB research seems rare. Patient advocates can have a valuable role in anything from designing the study and securing funding, to effectively communicating study results to patients and the general public.

Since the ecology and epidemiology of TBDs are diverse, yet greatly influence the burden of the different TBDs, these should also be considered. In addition, more awareness amongst physicians, prompt recognition of the various clinical symptoms and improved diagnostic tools could aid in combating TBDs in the future. A variety of personal and environment-based preventive and control measures exist, but suffer from the fact that they are not highly effective on their own. Combining them, and investing in fundamental as well as translational research, to be able to formulate (evidence-based) strategies on the control of TBDs might prove to be the way forward. Last, but most certainly not least, for most of the TBDs no vaccine exists and therefore research should most definitely focus on vaccine discovery and development. In that regard, vaccines targeting the tick vector, which could potentially prevent multiple TBPs, have the potential to become the next silver bullet, and require further investigation.

\footnotetext{
Abbreviations

ACA: Acrodermatitis chronica atrophicans; CSF: Cerebrospinal fluid; EM: Erythema migrans; GlpQ: Glycerophosphodiester phosphodiesterase; HTBRF: Hard tick-borne relapsing fever; LA: Lyme arthritis; LB: Lyme borreliosis; LNB: Lyme neuroborreliosis; TBD: Tick-borne disease; TBE(V): Tickborne encephalitis (virus); TBP: Tick-borne pathogen; Vmps: Variable major proteins
}

\section{Acknowledgements}

Not applicable.

\section{Funding}

This review was financially supported by the European Community's Seventh Framework Program under grant agreement 602272-2 (Project ANTIDotE) and by the Netherlands Organization for Scientific Research (ZON-MW grant 50-52200-98-313). AMN received financial support by the Federal Ministry of Education and Research (BMBF) under project number 01KI1720 as part of the 'Research Network Zoonotic Infectious Diseases'. The funders had no role in study design, data collection, interpretation and analysis, decision to publish or preparation of the manuscript.

\section{Availability of data and materials \\ Not applicable.}

\section{Authors' contributions}

HS and JWH initiated the review and drafted the outline. All authors have written one or more sections of the review. All authors read and approved the final manuscript.

Ethics approval and consent to participate Not applicable.

\section{Consent for publication}

Not applicable.

\section{Competing interests}

The authors declare that they have no competing interests.

\section{Publisher's Note}

Springer Nature remains neutral with regard to jurisdictional claims in published maps and institutional affiliations.

\section{Author details}

${ }^{1}$ Centre for Zoonoses \& Environmental Microbiology, Centre for Infectious Disease Control, National Institute for Public Health and the Environment, Bilthoven, the Netherlands. ${ }^{2}$ Institute for Parasitology and Tropical Veterinary Medicine, Freie Universität Berlin, Berlin, Germany. ${ }^{3}$ Center for Experimental. and Molecular Medicine, Academic Medical Center, Amsterdam, the Netherlands. ${ }^{4}$ Laboratory of Entomology, Wageningen University and Research Centre, Wageningen, the Netherlands.

Received: 4 January 2018 Accepted: 23 February 2018

Published online: 06 March 2018

\section{References}

1. Bircher AJ, Hofmeier KS, Link S, Heijnen I. Food allergy to the carbohydrate galactose-alpha-1,3-galactose (alpha-gal): four case reports and a review. Eur J Dermatol. 2017;27(1):3-9.

2. Apostolovic D, Tran TA, Starkhammar M, Sanchez-Vidaurre S, Hamsten C, Van Hage M. The red meat allergy syndrome in Sweden. Allergo J Int. 2016; 25(2):49-54.

3. Lindgren $E$, Andersson $Y$, Suk JE, Sudre B, Semenza JC. Public health. Monitoring EU emerging infectious disease risk due to climate change. Science. 2012;336(6080):418-9.

4. Smith R, borreliosis TJL. Europe-wide coordinated surveillance and action needed? Euro Surveill. 2006;11(6):E060622 1.

5. Bennet $L$, Halling A, Berglund J. Increased incidence of Lyme borreliosis in southern Sweden following mild winters and during warm, humid summers. Eur J Clin Microbiol Infect Dis. 2006;25(7):426-32.

6. Fulop B, Poggensee G. Epidemiological situation of Lyme borreliosis in Germany: surveillance data from six eastern German States, 2002 to 2006. Parasitol Res. 2008;103(Suppl. 1):S117-20.

7. Hofhuis A, Bennema S, Harms M, van Vliet AJ, Takken W, van den Wijngaard CC, et al. Decrease in tick bite consultations and stabilization of early Lyme borreliosis in the Netherlands in 2014 after 15 years of continuous increase. BMC Public Health. 2016;16:425.

8. Jaenson TG, Hjertqvist M, Bergstrom T, Lundkvist A. Why is tick-borne encephalitis increasing? A review of the key factors causing the increasing incidence of human TBE in Sweden. Parasit Vectors. 2012;5:184. 
9. Kunze U. The International Scientific Working Group on Tick-Borne Encephalitis (ISW TBE): review of 17 years of activity and commitment. Ticks Tick Borne Dis. 2016;7(3):399-404.

10. Edouard S, Koebel C, Goehringer F, Socolovschi C, Jaulhac B, Raoult D, et al. Emergence of human granulocytic anaplasmosis in France. Ticks Tick Borne Dis. 2012;3(5-6):403-5.

11. Hing M, Woestyn S, Van Bosterhaut B, Desbonnet $Y$, Heyman P, Cochez C, et al. Diagnosis of human granulocytic anaplasmosis in Belgium by combining molecular and serological methods. New Microbes New Infect. 2014;2(6):177-8.

12. Jahfari S, Hofhuis A, Fonville M, van der Giessen J, van Pelt W, Sprong H. Molecular Detection of tick-borne pathogens in humans with tick bites and erythema migrans, in the Netherlands. PLoS Negl Trop Dis. 2016;10(10): e0005042.

13. Koetsveld J, Tijsse-Klasen E, Herremans T, Hovius JW, Sprong H. Serological and molecular evidence for spotted fever group Rickettsia and Borrelia burgdorferi sensu lato co-infections in The Netherlands. Ticks Tick Borne Dis. 2016;7(2):371-7.

14. Lotric-Furlan S, Rojko T, Jelovsek M, Petrovec M, Avsic-Zupanc T, Lusa L, et al. Comparison of clinical and laboratory characteristics of patients fulfilling criteria for proven and probable human granulocytic anaplasmosis. Microbes Infect. 2015;17(11-12):829-33.

15. Quarsten H, Grankvist A, Hoyvoll L, Myre IB, Skarpaas T, Kjelland V, et al. "Candidatus Neoehrlichia mikurensis" and Borrelia burgdorferi sensu lato detected in the blood of Norwegian patients with erythema migrans. Ticks Tick Borne Dis. 2017:8(5):715-20.

16. Silaghi C, Beck R, Oteo JA, Pfeffer M, Sprong H. Neoehrlichiosis: an emerging tick-borne zoonosis caused by "Candidatus Neoehrlichia mikurensis". Exp Appl Acarol. 2016;68(3):279-97.

17. Wagemakers A, Staarink PJ, Sprong H, Hovius JW. Borrelia miyamotoi: a widespread tick-borne relapsing fever spirochete. Trends Parasitol. 2015; 31(6):260-9

18. Gilbert L. Louping ill virus in the UK: a review of the hosts, transmission and ecological consequences of control. Exp Appl Acarol. 2016;68(3):363-74.

19. Leschnik MW, Kirtz GC, Thalhammer JG. Tick-borne encephalitis (TBE) in dogs. Int J Med Microbiol. 2002;291(Suppl. 33):66-9.

20. Pantchev N, Pluta S, Huisinga E, Nather S, Scheufelen M, Vrhovec MG, et al. Tick-borne diseases (borreliosis, anaplasmosis, babesiosis) in German and Austrian dogs: status quo and review of distribution, rransmission, clinical findings, diagnostics and prophylaxis. Parasitol Res. 2015;114(Suppl. 1):S19-54.

21. Zintl A, Mulcahy G, Skerrett HE, Taylor SM, Gray JS. Babesia divergens, a bovine blood parasite of veterinary and zoonotic importance. Clin Microbiol Rev. 2003;16(4):622-36.

22. Feder HM Jr, Johnson BJ, O'Connell S, Shapiro ED, Steere AC, Wormser GP, et al. A critical appraisal of "chronic Lyme disease". N Engl J Med. 2007; 357(14):1422-30.

23. Stanek G, Wormser GP, Gray J, Strle F. Lyme borreliosis. Lancet. 2012; 379(9814):461-73.

24. Lantos PM. Chronic Lyme disease: the controversies and the science. Expert Rev Anti-Infect Ther. 2011;9(7):787-97.

25. Moutailler S, Valiente Moro C, Vaumourin E, Michelet L, Tran FH, Devillers E, et al. Co-infection of ticks: the rule rather than the exception. PLoS Negl Trop Dis. 2016;10(3):e0004539.

26. Hovius JW, Sprong H. Combatting Lyme disease. Ned Tijdschr Geneeskd. 2014;158:A7986

27. Eisen RJ, Eisen L. The blacklegged tick, Ixodes scapularis: an increasing public health concern. Trends Parasitol. 2018; https:/doi.org/10.1016/j.pt.2017.12.006.

28. Randolph SE. Tick ecology: processes and patterns behind the epidemiological risk posed by ixodid ticks as vectors. Parasitology. 2004; 129(Suppl.):S37-65.

29. Hofmeester TR, Coipan EC, Van Wieren SE, Prins HHT, Takken W, Sprong H. Few vertebrate species dominate the Borrelia burgdorferi s.l. life cycle. Environ Res Lett. 2016;11(4):1-16.

30. Hofmeester TR, Sprong H, Jansen PA, Prins HHT, van Wieren SE. Deer presence rather than abundance determines the population density of the sheep tick, Ixodes ricinus, in Dutch forests. Parasit Vectors. 2017;10:433.

31. Lindgren $\mathrm{E}$, Talleklint $\mathrm{L}$, Polfeldt $\mathrm{T}$. Impact of climatic change on the northern latitude limit and population density of the disease-transmitting European tick Ixodes ricinus. Environ Health Perspect. 2000;108(2):119-23.

32. Gray JS, Dautel H, Estrada-Pena A, Kahl O, Lindgren E. Effects of climate change on ticks and tick-borne diseases in europe. Interdiscip Perspect Infect Dis. 2009;2009:593232.
33. Estrada-Pena A, Farkas R, Jaenson TG, Koenen F, Madder M, Pascucci I, et al. Association of environmental traits with the geographic ranges of ticks (Acari: Ixodidae) of medical and veterinary importance in the western Palearctic. A digital data set. Exp Appl Acarol. 2013;59(3):351-66.

34. Coipan EC, Jahfari S, Fonville M, Maassen CB, van der Giessen J, Takken W, et al. Spatiotemporal dynamics of emerging pathogens in questing Ixodes ricinus. Front Cell Infect Microbiol. 2013;3:36.

35. Sprong H, Hofhuis A, Gassner F, Takken W, Jacobs F, van Vliet AJ, et al. Circumstantial evidence for an increase in the total number and activity of Borrelia-infected Ixodes ricinus in the Netherlands. Parasit Vectors. 2012;5:294.

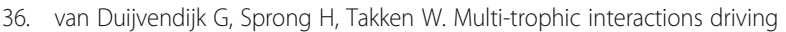
the transmission cycle of Borrelia afzelii between Ixodes ricinus and rodents: a review. Parasit Vectors. 2015:8:643

37. Guy EC, Farquhar RG. Borrelia burgdorferi in urban parks. Lancet. 1991; 338(8761):253.

38. Hansford KM, Fonville M, Gillingham EL, Coipan EC, Pietzsch ME, Krawczyk Al, et al. Ticks and Borrelia in urban and peri-urban green space habitats in a city in southern England. Ticks Tick Borne Dis. 2017:8(3):353-61.

39. Foldvari G, Jahfari S, Rigo K, Jablonszky M, Szekeres S, Majoros G, et al. "Candidatus Neoehrlichia mikurensis" and Anaplasma phagocytophilum in urban hedgehogs. Emerg Infect Dis. 2014;20(3):496-8.

40. Jahfari S, Ruyts SC, Frazer-Mendelewska E, Jaarsma R, Verheyen K, Sprong H. Melting pot of tick-borne zoonoses: the European hedgehog contributes to the maintenance of various tick-borne diseases in natural cycles urban and suburban areas. Parasit Vectors. 2017:10(1):134.

41. Medlock JM, Hansford KM, Bormane A, Derdakova M, Estrada-Pena A, George JC, et al. Driving forces for changes in geographical distribution of Ixodes ricinus ticks in Europe. Parasit Vectors. 2013;6:1.

42. Kauppi PE, Ausubel JH, Fang J, Mather AS, Sedjo RA, Waggoner PE. Returning forests analyzed with the forest identity. Proc Natl Acad Sci USA. 2006;103(46):17574-9.

43. Barbour AG, Fish D. The biological and social phenomenon of Lyme disease. Science. 1993;260(5114):1610-6

44. Spielman A. The emergence of Lyme disease and human babesiosis in a changing environment. Ann N Y Acad Sci. 1994;740:146-56.

45. Ruyts SC, Ampoorter E, Coipan EC, Baeten L, Heylen D, Sprong H, et al. Diversifying forest communities may change Lyme disease risk: extra dimension to the dilution effect in Europe. Parasitology. 2016;143(10):1310-9.

46. Hobbs R. Woodland restoration in Scotland: ecology, history, culture, economics, politics and change. J Environ Manag. 2009;90(9):2857-65.

47. European Commission. (2017). http://ec.europa.eu/environment/nature. Accessed 1 Dec 2017.

48. Maetzel D, Maier WA, Kampen H. Borrelia burgdorferi infection prevalences in questing Ixodes ricinus ticks (Acari: Ixodidae) in urban and suburban Bonn, western Germany. Parasitol Res. 2005;95(1):5-12.

49. Paul RE, Cote M, Le Naour E, Bonnet SI. Environmental factors influencing tick densities over seven years in a French suburban forest. Parasit Vectors. 2016;9:309.

50. Vourc'h G, Abrial D, Bord S, Jacquot M, Masseglia S, Poux V, et al. Mapping human risk of infection with Borrelia burgdorferi sensu lato, the agent of Lyme borreliosis, in a periurban forest in France. Ticks Tick Borne Dis. 2016;7(5):644-52.

51. van Duijvendijk G, Coipan C, Wagemakers A, Fonville M, Ersoz J, Oei A, et al. Larvae of Ixodes ricinus transmit Borrelia afzelii and B. miyamotoi to vertebrate hosts. Parasit Vectors. 2016:9:97.

52. Gray J, von Stedingk LV, Gurtelschmid M, Granstrom M. Transmission studies of Babesia microti in Ixodes ricinus ticks and gerbils. J Clin Microbiol. 2002:40(4):1259-63.

53. Bonnet $\mathrm{S}$, Jouglin M, L'Hostis M, Chauvin A. Babesia sp. EU1 from roe deer and transmission within Ixodes ricinus. Emerg Infect Dis. 2007;13(8):1208-10.

54. Sprong $\mathrm{H}$, Wielinga PR, Fonville M, Reusken C, Brandenburg AH, Borgsteede $\mathrm{F}$, et al. Ixodes ricinus ticks are reservoir hosts for Rickettsia helvetica and potentially carry flea-borne Rickettsia species. Parasit Vectors. 2009;2:41.

55. de la Fuente J, Antunes S, Bonnet S, Cabezas-Cruz A, Domingos AG, Estrada-Pena $A$, et al. Tick-pathogen interactions and vector competence: identification of molecular drivers for tick-borne diseases. Front Cell Infect Microbiol. 2017;7:114.

56. Gylfe A, Bergstrom S, Lundstrom J, Olsen B. Reactivation of Borrelia infection in birds. Nature. 2000;403(6771):724-5.

57. Thomas RJ, Birtles RJ, Radford AD, Woldehiwet Z. Recurrent bacteraemia in sheep infected persistently with Anaplasma phagocytophilum. J Comp Pathol. 2012:147(2-3):360-7.

58. Telfer S, Lambin X, Birtles R, Beldomenico P, Burthe S, Paterson S, et al. Species interactions in a parasite community drive infection risk in a wildlife population. Science. 2010;330(6001):243-6. 
59. LoGiudice K, Ostfeld RS, Schmidt KA, Keesing F. The ecology of infectious disease: effects of host diversity and community composition on Lyme disease risk. Proc Natl Acad Sci USA. 2003;100(2):567-71.

60. Randolph SE, Dobson AD. Pangloss revisited: a critique of the dilution effect and the biodiversity-buffers-disease paradigm. Parasitology. 2012;139(7):847-63.

61. Hofmeester TR, Jansen PA, Wijnen HJ, Coipan EC, Fonville M, Prins HHT, et al. Cascading effects of predator activity on tick-borne disease risk. Proc Biol Sci. 2017;284:20170453.

62. Randolph SE, Miklisova D, Lysy J, Rogers DJ, Labuda M. Incidence from coincidence: patterns of tick infestations on rodents facilitate transmission of tick-borne encephalitis virus. Parasitology. 1999;118(2):177-86.

63. Randolph SE, Green RM, Peacey MF, Rogers DJ. Seasonal synchrony: the key to tick-borne encephalitis foci identified by satellite data. Parasitology. 2000; 121(1):15-23.

64. Randolph SE, Rogers DJ. Fragile transmission cycles of tick-borne encephalitis virus may be disrupted by predicted climate change. Proc Biol Sci. 2000;267(1454):1741-4

65. Strnad M, Honig V, Ruzek D, Grubhoffer L, Rego ROM. Europe-wide metaanalysis of Borrelia burgdorferi sensu lato prevalence in questing Ixodes ricinus ticks. Appl Environ Microbiol. 2017;83(15):e00609-17.

66. Coipan EC, Jahfari S, Fonville M, Oei GA, Spanjaard L, Takumi K, et al. Imbalanced presence of Borrelia burgdorferi s.l. multilocus sequence types in clinical manifestations of Lyme borreliosis. Infect Genet Evol. 2016;42:66-76.

67. Braks M, van der Giessen J, Kretzschmar M, van Pelt W, Scholte EJ, Reusken C, et al. Towards an integrated approach in surveillance of vector-borne diseases in Europe. Parasit Vectors. 2011;4:192.

68. European Centre for Disease Prevention and Control. Epidemiological situation of tick-borne encephalitis in the European Union and European Free Trade Association countries. In: European Centre for Disease Prevention and Control (ECDC). Stockholm: European Centre for Disease Prevention and Control; 2013. https://doi.org/10.2900/62311.

69. Smit R, Postma MJ. The burden of tick-borne encephalitis in disabilityadjusted life years (DALYS) for Slovenia. PLoS One. 2015;10(12):e0144988.

70. Jahfari S, de Vries A, Rijks JM, Van Gucht S, Vennema H, Sprong H, et al. Tick-borne encephalitis virus in ticks and roe deer, the Netherlands. Emerg Infect Dis. 2017;23(6):1028-30.

71. Hofhuis A, Harms M, Bennema S, van den Wijngaard CC, van Pelt W. Physician reported incidence of early and late Lyme borreliosis. Parasit Vectors. 2015;8:161.

72. van den Wijngaard CC, Hofhuis A, Simoes M, Rood E, van Pelt W, Zeller $H$, et al. Surveillance perspective on Lyme borreliosis across the European Union and European Economic Area. Euro Surveill. 2017;22(27).

73. Huppertz HI, Bohme M, Standaert SM, Karch H, Plotkin SA. Incidence of Lyme borreliosis in the Wurzburg region of Germany. Eur J Clin Microbiol Infect Dis. 1999;18(10):697-703.

74. van den Wijngaard CC, Hofhuis A, Harms MG, Haagsma JA, Wong A, de Wit $\mathrm{GA}$, et al. The burden of Lyme borreliosis expressed in disability-adjusted life years. Eur J Pub Health. 2015;25(6):1071-8

75. Heyman P, Cochez C, Hofhuis A, van der Giessen J, Sprong H, Porter SR, et al. A clear and present danger: tick-borne diseases in Europe. Expert Rev Anti-Infect Ther. 2010;8(1):33-50.

76. Cochez C, Ducoffre G, Vandenvelde C, Luyasu V, Heyman P. Human anaplasmosis in Belgium: a 10-year seroepidemiological study. Ticks Tick Borne Dis. 2011;2(3):156-9.

77. Kalinova Z, Halanova M, Cislakova L, Sulinova Z, Jarcuska P. Occurrence of IgG antibodies to Anaplasma phagocytophilum in humans suspected of Lyme borreliosis in eastern Slovakia. Ann Agric Environ Med. 2009;16(2):285-8.

78. von Wissmann B, Hautmann W, Sing A, Hizo-Teufel C, Fingerle V. Assessing the risk of human granulocytic anaplasmosis and Lyme borreliosis after a tick bite in Bavaria, Germany. Int J Med Microbiol. 2015:305(7):736-41.

79. De Keukeleire M, Vanwambeke SO, Cochez C, Heyman P, Fretin D, Deneys $\checkmark$, et al. Seroprevalence of Borrelia burgdorferi, Anaplasma phagocytophilum, and Francisella tularensis infections in Belgium: results of three populationbased samples. Vector Borne Zoonotic Dis. 2017;17(2):108-15.

80. Sprong H, Tijsse-Klasen E, Langelaar M, De Bruin A, Fonville M, Gassner F, et al. Prevalence of Coxiella burnetii in ticks after a large outbreak of $Q$ fever. Zoonoses Public Health. 2012:59(1):69-75.

81. Steere AC, Strle F, Wormser GP, Hu LT, Branda JA, Hovius JW, et al. Lyme borreliosis. Nat Rev Dis Primers. 2016;2:16090.

82. Stanek G, Fingerle V, Hunfeld KP, Jaulhac B, Kaiser R, Krause A, et al. Lyme borreliosis: clinical case definitions for diagnosis and management in Europe. Clin Microbiol Infect. 2011;17(1):69-79.
83. Ogrinc K, Wormser GP, Visintainer P, Maraspin V, Lotric-Furlan S, Cimperman J, et al. Pathogenetic implications of the age at time of diagnosis and skin location for acrodermatitis chronica atrophicans. Ticks Tick Borne Dis. 2017; 8(2):266-9.

84. Hovius JW. PS. Chronic Lyme disease: a confusing entity. Tijdschrift Infect. 2012;7:20-9.

85. Coumou J, Herkes EA, Brouwer MC, van de Beek D, Tas SW, Casteelen G, et al. Ticking the right boxes: classification of patients suspected of Lyme borreliosis at an academic referral center in the Netherlands. Clin Microbiol Infect. 2015;21(4):368 e11-20.

86. Piantedosi D, Neola B, D'Alessio N, Di Prisco F, Santoro M, Pacifico L, et al. Seroprevalence and risk factors associated with Ehrlichia canis, Anaplasma spp., Borrelia burgdorferi sensu lato, and D. immitis in hunting dogs from southern Italy. Parasitol Res. 2017;116(10):2651-60.

87. Savic S, Vidic B, Lazic S, Lako B, Potkonjak A, Lepsanovic Z. Borrelia burgdorferi in ticks and dogs in the province of Vojvodina, Serbia. Parasite. 2010;17(4):357-61

88. Laus F, Veronesi F, Passamonti F, Paggi E, Cerquetella M, Hyatt D, et al. Prevalence of tick borne pathogens in horses from Italy. J Vet Med Sci. 2013;75(6):715-20.

89. Maurizi L, Marie JL, Aoun O, Courtin C, Gorsane S, Chal D, et al. Seroprevalence survey of equine Lyme borreliosis in France and in subSaharan Africa. Vector Borne Zoonotic Dis. 2010;10(5):535-7.

90. Grauer GF, Burgess EC, Cooley AJ, Hagee JH. Renal lesions associated with Borrelia burgdorferi infection in a dog. J Am Vet Med Assoc. 1988; 193(2):237-9.

91. Appel MJ, Allan S, Jacobson RH, Lauderdale TL, Chang YF, Shin SJ, et al. Experimental Lyme disease in dogs produces arthritis and persistent infection. J Infect Dis. 1993;167(3):651-64.

92. Hovius KE, Stark LA, Bleumink-Pluym NM, van de Pol I, Verbeek-de Kruif N, Rijpkema SG, et al. Presence and distribution of Borrelia burgdorferi sensu lato species in internal organs and skin of naturally infected symptomatic and asymptomatic dogs, as detected by polymerase chain reaction. Vet $\mathrm{Q}$. 1999;21(2):54-8.

93. Imai DM, Barr BC, Daft B, Bertone JJ, Feng S, Hodzic E, et al. Lyme neuroborreliosis in 2 horses. Vet Pathol. 2011;48(6):1151-7.

94. Priest HL, Irby NL, Schlafer DH, Divers TJ, Wagner B, Glaser AL, et al. Diagnosis of Borrelia-associated uveitis in two horses. Vet Ophthalmol. 2012; 15(6):398-405.

95. Lappin MR, Chandrashekar R, Stillman B, Liu J, Mather TN. Evidence of Anaplasma phagocytophilum and Borrelia burgdorferi infection in cats after exposure to wild-caught adult Ixodes scapularis. J Vet Diagn Investig. 2015; 27(4):522-5

96. Straubinger RK, Straubinger AF, Summers BA, Jacobson RH, Erb HN. Clinical manifestations, pathogenesis, and effect of antibiotic treatment on Lyme borreliosis in dogs. Wien Klin Wochenschr. 1998;110(24):874-81.

97. Magnarelli LA, ljdo JW, Van Andel AE, Wu C, Padula SJ, Fikrig E. Serologic confirmation of Ehrlichia equi and Borrelia burgdorferi infections in horses from the northeastern United States. J Am Vet Med Assoc. 2000;217(7):1045-50.

98. James FM, Engiles JB, Beech J. Meningitis, cranial neuritis, and radiculoneuritis associated with Borrelia burgdorferi infection in a horse. J Am Vet Med Assoc. 2010;237(10):1180-5.

99. Chang YF, McDonough SP, Chang CF, Shin KS, Yen W, Divers T. Human granulocytic ehrlichiosis agent infection in a pony vaccinated with a Borrelia burgdorferi recombinant OspA vaccine and challenged by exposure to naturally infected ticks. Clin Diagn Lab Immunol. 2000;7(1):68-71.

100. Beall MJ, Chandrashekar R, Eberts MD, Cyr KE, Diniz PP, Mainville C, et al. Serological and molecular prevalence of Borrelia burgdorferi, Anaplasma phagocytophilum, and Ehrlichia species in dogs from Minnesota. Vector Borne Zoonotic Dis. 2008;8(4):455-64.

101. Kaiser R. Tick-borne encephalitis. Infect Dis Clin N Am. 2008;22(3):561-75.

102. Gunther G, Haglund M, Lindquist L, Forsgren M, Skoldenberg B. Tick-bone encephalitis in Sweden in relation to aseptic meningo-encephalitis of other etiology: a prospective study of clinical course and outcome. J Neurol. 1997; 244(4):230-8.

103. Kaiser R. The clinical and epidemiological profile of tick-borne encephalitis in southern Germany 1994-98: a prospective study of 656 patients. Brain. 1999:122(11):2067-78.

104. Taba P, Schmutzhard E, Forsberg P, Lutsar I, Ljostad U, Mygland A, et al. EAN consensus review on prevention, diagnosis and management of tick-borne encephalitis. Eur J Neurol. 2017;24(10):1214-e61. 
105. Haglund M, Gunther G. Tick-borne encephalitis - pathogenesis, clinical course and long-term follow-up. Vaccine. 2003;21(Suppl. 1):S11-8.

106. Pfeffer M, Dobler G. Tick-borne encephalitis virus in dogs - is this an issue? Parasit Vectors. 2011:4:59.

107. Bakken JS, Dumler S. Human granulocytic anaplasmosis. Infect Dis Clin N Am. 2008;22(3):433-48

108. Aguero-Rosenfeld ME, Horowitz HW, Wormser GP, McKenna DF, Nowakowski J, Munoz J, et al. Human granulocytic ehrlichiosis: a case series from a medical center in New York State. Ann Intern Med. 1996;125(11):904-8.

109. Bakken JS, Krueth J, Wilson-Nordskog C, Tilden RL, Asanovich K, Dumler JS Clinical and laboratory characteristics of human granulocytic ehrlichiosis. JAMA. 1996;275(3):199-205.

110. Annen K, Friedman K, Eshoa C, Horowitz M, Gottschall J, Straus T. Two cases of transfusion-transmitted Anaplasma phagocytophilum. Am J Clin Pathol. 2012;137(4):562-5.

111. Alhumaidan H, Westley B, Esteva C, Berardi V, Young C, Sweeney J. Transfusion-transmitted anaplasmosis from leukoreduced red blood cells. Transfusion. 2013;53(1):181-6.

112. Regan J, Matthias J, Green-Murphy A, Stanek D, Bertholf M, Pritt BS, et al. A confirmed Ehrlichia ewingii infection likely acquired through platelet transfusion. Clin Infect Dis. 2013;56(12):e105-7.

113. Stuen S, Granquist EG, Silaghi C. Anaplasma phagocytophilum - a widespread multi-host pathogen with highly adaptive strategies. Front Cell Infect Microbiol. 2013;3:31.

114. Platonov AE, Karan LS, Kolyasnikova NM, Makhneva NA, Toporkova MG, Maleev W, et al. Humans infected with relapsing fever spirochete Borrelia miyamotoi, Russia. Emerg Infect Dis. 2011;17(10):1816-23.

115. Brouqui P, Bacellar F, Baranton G, Birtles RJ, Bjoersdorff A, Blanco JR, et al. Guidelines for the diagnosis of tick-borne bacterial diseases in Europe. Clin Microbiol Infect. 2004;10(12):1108-32.

116. Chowdri HR, Gugliotta JL, Berardi VP, Goethert HK, Molloy PJ, Sterling SL, et al. Borrelia miyamotoi infection presenting as human granulocytic anaplasmosis: a case report. Ann Intern Med. 2013;159(1):21-7.

117. Krause PJ, Fish D, Narasimhan S, Barbour AG. Borrelia miyamotoi infection in nature and in humans. Clin Microbiol Infect. 2015;21(7):631-9.

118. Molloy PJ, Telford SR 3rd, Chowdri HR, Lepore TJ, Gugliotta JL, Weeks KE, et al. Borrelia miyamotoi disease in the northeastern United States: a case series. Ann Intern Med. 2015;163(2):91-8.

119. Roux V, Raoult D. Phylogenetic analysis of the genus Rickettsia by 165 rDNA sequencing. Res Microbiol. 1995;146(5):385-96.

120. Raoult D, Roux V. Rickettsioses as paradigms of new or emerging infectious diseases. Clin Microbiol Rev. 1997;10(4):694-719.

121. Fournier PE, Grunnenberger F, Jaulhac B, Gastinger G, Raoult D. Evidence of Rickettsia helvetica infection in humans, eastern France. Emerg Infect Dis. 2000;6(4):389-92.

122. Nielsen H, Fournier PE, Pedersen IS, Krarup H, Ejlertsen T, Raoult D. Serological and molecular evidence of Rickettsia helvetica in Denmark. Scand J Infect Dis. 2004;36(8):559-63.

123. Parola P, Paddock CD, Raoult D. Tick-borne rickettsioses around the world: emerging diseases challenging old concepts. Clin Microbiol Rev. 2005;18(4):719-56.

124. Nilsson K, Elfving K, Pahlson C. Rickettsia helvetica in patient with meningitis, Sweden, 2006. Emerg Infect Dis. 2010;16(3):490-2.

125. Merhej $V$, Raoult D. Rickettsial evolution in the light of comparative genomics. Biol Rev Camb Philos Soc. 2011;86(2):379-405.

126. Nilsson K, Wallmenius K, Pahlson C. Coinfection with Rickettsia helvetica and Herpes Simplex Virus 2 in a young woman with meningoencephalitis. Case Rep Infect Dis. 2011;2011:469194.

127. Jado I, Oteo JA, Aldamiz M, Gil H, Escudero R, Ibarra V, et al. Rickettsia monacensis and human disease, Spain. Emerg Infect Dis. 2007;13(9):1405-7.

128. Madeddu G, Mancini F, Caddeo A, Ciervo A, Babudieri S, Maida I, et al. Rickettsia monacensis as cause of Mediterranean spotted fever-like illness, Italy. Emerg Infect Dis. 2012;18(4):702-4.

129. Tijsse-Klasen E, Sprong H, Pandak N. Co-infection of Borrelia burgdorferi sensu lato and Rickettsia species in ticks and in an erythema migrans patient. Parasit Vectors. 2013;6:347.

130. Criado-Fornelio A, Martinez-Marcos A, Buling-Sarana A, Barba-Carretero JC. Molecular studies on Babesia, Theileria and Hepatozoon in southern Europe. Part II. Phylogenetic analysis and evolutionary history. Vet Parasitol. 2003; 114(3):173-94.

131. Goethert HK, Telford SR 3rd. What is Babesia microti? Parasitology. 2003; 127(4):301-9.
132. Conrad PA, Kjemtrup AM, Carreno RA, Thomford J, Wainwright K, Eberhard M, et al. Description of Babesia duncani n.sp. (Apicomplexa: Babesiidae) from humans and its differentiation from other piroplasms. Int J Parasitol. 2006:36(7):779-89.

133. Ruebush TK 2nd, Juranek DD, Chisholm ES, Snow PC, Healy GR, Sulzer AJ. Human babesiosis on Nantucket Island. Evidence for self-limited and subclinical infections. N Engl J Med. 1977;297(15):825-7.

134. Homer MJ, Aguilar-Delfin I, Telford SR 3rd, Krause PJ, Persing DH. Babesiosis. Clin Microbiol Rev. 2000;13(3):451-69.

135. Eskow E, Rao RV, Mordechai E. Concurrent infection of the central nervous system by Borrelia burgdorferi and Bartonella henselae: evidence for a novel tick-borne disease complex. Arch Neurol. 2001;58(9):1357-63.

136. Gromova OA, Etenko DA, Semenov VA, Subbotin AV. Diagnosis of mixed tick-borne encephalitis and tick-borne borreliosis in the early stages of the disease. Zh Nevrol Psikhiatr Im S S Korsakova. 2013;113(4):9-12 (In Russian).

137. Krause PJ, Telford SR 3rd, Spielman A, Sikand V, Ryan R, Christianson D, et al. Concurrent Lyme disease and babesiosis. Evidence for increased severity and duration of illness. JAMA. 1996;275(21):1657-60.

138. Belongia EA. Epidemiology and impact of coinfections acquired from Ixodes ticks. Vector Borne Zoonotic Dis. 2002;2(4):265-73.

139. Krause PJ, McKay K, Thompson CA, Sikand VK, Lentz R, Lepore T, et al. Diseasespecific diagnosis of coinfecting tickborne zoonoses: babesiosis, human granulocytic ehrlichiosis, and Lyme disease. Clin Infect Dis. 2002;34(9):1184-91.

140. Swanson SJ, Neitzel D, Reed KD, Belongia EA. Coinfections acquired from Ixodes ticks. Clin Microbiol Rev. 2006;19(4):708-27.

141. Knapp KL, Rice NA. Human coinfection with Borrelia burgdorferi and Babesia microti in the United States. J Parasitol Res. 2015;2015:587131.

142. Diuk-Wasser MA, Vannier E, Krause PJ. Coinfection by Ixodes tick-borne pathogens: ecological, epidemiological, and clinical consequences. Trends Parasitol. 2016;32(1):30-42

143. Steere AC, McHugh G, Suarez C, Hoitt J, Damle N, Sikand VK. Prospective study of coinfection in patients with erythema migrans. Clin Infect Dis. 2003;36(8):1078-81.

144. Tijsse-Klasen E, Jacobs JJ, Swart A, Fonville M, Reimerink JH, Brandenburg $\mathrm{AH}$, et al. Small risk of developing symptomatic tick-borne diseases following a tick bite in the Netherlands. Parasit Vectors. 2011;4:17.

145. Moniuszko A, Dunaj J, Swiecicka I, Zambrowski G, Chmielewska-Badora J, Zukiewicz-Sobczak W, et al. Co-infections with Borrelia species, Anaplasma phagocytophilum and Babesia spp. in patients with tick-borne encephalitis. Eur J Clin Microbiol Infect Dis. 2014;33(10):1835-41.

146. Strle F, Bogovic P, Cimperman J, Maraspin V, Ogrinc K, Rojko T, et al. Are patients with erythema migrans who have leukopenia and/or thrombocytopenia coinfected with Anaplasma phagocytophilum or tickborne encephalitis virus? PLoS One. 2014;9(7):e103188.

147. Halperin JJ, Wormser GP. Of fleas and ticks on cats and mice. Arch Neurol. 2001;58(9):1345-7.

148. Lantos PM, Wormser GP. Chronic coinfections in patients diagnosed with chronic Lyme disease: a systematic review. Am J Med. 2014;127(11):1105-10.

149. Leeflang MM, Ang CW, Berkhout J, Bijlmer HA, Van Bortel W, Brandenburg $\mathrm{AH}$, et al. The diagnostic accuracy of serological tests for Lyme borreliosis in Europe: a systematic review and meta-analysis. BMC Infect Dis. 2016;16:140.

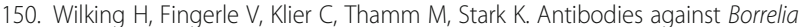
burgdorferi sensu lato among Adults, Germany, 2008-2011. Emerg Infect Dis. 2015;21(1):107-10.

151. Hammers-Berggren S, Lebech AM, Karlsson M, Svenungsson B, Hansen K, Stiernstedt G. Serological follow-up after treatment of patients with erythema migrans and neuroborreliosis. J Clin Microbiol. 1994;32(6):1519-25.

152. Aguero-Rosenfeld ME, Nowakowski J, Bittker S, Cooper D, Nadelman RB, Wormser GP. Evolution of the serologic response to Borrelia burgdorferi in treated patients with culture-confirmed erythema migrans. J Clin Microbiol. 1996;34(1):1-9.

153. Kalish RA, McHugh G, Granquist J, Shea B, Ruthazer R, Steere AC. Persistence of immunoglobulin $\mathrm{M}$ or immunoglobulin $\mathrm{G}$ antibody responses to Borrelia burgdorferi 10-20 years after active Lyme disease. Clin Infect Dis. 2001;33(6):780-5.

154. Forselv KJN, Lorentzen AR, Ljostad U, Mygland A, Eikeland R, Kjelland V, et al. Does more favourable handling of the cerebrospinal fluid increase the diagnostic sensitivity of Borrelia burgdorferi sensu lato-specific PCR in Lyme neuroborreliosis? Infect Dis (Lond). 2017; https://doi.org/10.1080/23744235.2017.1399315.

155. Dessau RB, van Dam AP, Fingerle V, Gray J, Hovius JW, Hunfeld KP, et al. To test or not to test? Laboratory support for the diagnosis of Lyme borreliosis: a position paper of ESGBOR, the ESCMID study group for Lyme borreliosis. Clin Microbiol Infect. 2018;24(2):118-24 
156. Koedel U, Fingerle V, Pfister HW. Lyme neuroborreliosis - epidemiology, diagnosis and management. Nat Rev Neurol. 2015;11(8):446-56.

157. Jin C, Roen DR, Lehmann PV, Kellermann GH. An enhanced ELISPOT assay for sensitive detection of antigen-specific T cell responses to Borrelia burgdorferi. Cell. 2013;2(3):607-20.

158. von Baehr V, Doebis C, Volk HD, von Baehr R. The lymphocyte transformation test for Borrelia detects active Lyme borreliosis and verifies effective antibiotic treatment. Open Neurol J. 2012;6:104-12.

159. Dessau RB, Fingerle V, Gray J, Hunfeld KP, Jaulhac B, Kahl O, et al. The lymphocyte transformation test for the diagnosis of Lyme borreliosis has currently not been shown to be clinically useful. Clin Microbiol Infect. 2014; 20(10):O786-7.

160. Cattaruzza F, Cenac N, Barocelli E, Impicciatore M, Hyun E, Vergnolle N, et al. Protective effect of proteinase-activated receptor 2 activation on motility impairment and tissue damage induced by intestinal ischemia/reperfusion in rodents. Am J Pathol. 2006;169(1):177-88.

161. Aase A, Hajdusek O, Oines O, Quarsten H, Wilhelmsson P, Herstad TK, et al. Validate or falsify: Lessons learned from a microscopy method claimed to be useful for detecting Borrelia and Babesia organisms in human blood. Infect Dis (Lond). 2016;48(6):411-9.

162. Littman MP, Goldstein RE, Labato MA, Lappin MR, Moore GE. ACVIM small animal consensus statement on Lyme disease in dogs: diagnosis, treatment, and prevention. J Vet Intern Med. 2006;20(2):422-34.

163. Lindquist L, Vapalahti O. Tick-borne encephalitis. Lancet. 2008:371(9627):1861-71.

164. Holzmann H. Diagnosis of tick-borne encephalitis. Vaccine. 2003;21(Suppl. 1): S36-40.

165. Bakken JS, Aguero-Rosenfeld ME, Tilden RL, Wormser GP, Horowitz HW, Raffalli JT, et al. Serial measurements of hematologic counts during the active phase of human granulocytic ehrlichiosis. Clin Infect Dis. 2001;32(6):862-70.

166. Vannier EG, Diuk-Wasser MA, Ben Mamoun C, Krause PJ. Babesiosis. Infect Dis Clin N Am. 2015;29(2):357-70.

167. Gugliotta JL, Goethert HK, Berardi VP, Telford SR 3rd. Meningoencephalitis from Borrelia miyamotoi in an immunocompromised patient. N Engl J Med. 2013;368(3):240-5.

168. Hovius JW, de Wever B, Sohne M, Brouwer MC, Coumou J, Wagemakers A, et al. A case of meningoencephalitis by the relapsing fever spirochaete Borrelia miyamotoi in Europe. Lancet. 2013;382(9892):658.

169. Wormser GP, Dattwyler RJ, Shapiro ED, Halperin JJ, Steere AC, Klempner MS, et al. The clinical assessment, treatment, and prevention of Lyme disease, human granulocytic anaplasmosis, and babesiosis: clinical practice guidelines by the Infectious Diseases Society of America. Clin Infect Dis. 2006:43(9):1089-134.

170. Dumler JS, Madigan JE, Pusterla N, Bakken JS. Ehrlichioses in humans: epidemiology, clinical presentation, diagnosis, and treatment. Clin Infect Dis. 2007;45(Suppl. 1):S45-51.

171. Dumler JS, Bakken JS. Ehrlichial diseases of humans: emerging tick-borne infections. Clin Infect Dis. 1995;20(5):1102-10.

172. Rolain JM, Shpynov S, Raoult D. Spotted-fever-group rickettsioses in north Asia. Lancet. 2003;362(9399):1939.

173. Chapman AS, Bakken JS, Folk SM, Paddock CD, Bloch KC, Krusell A, et al. Diagnosis and management of tickborne rickettsial diseases: Rocky Mountain spotted fever, ehrlichioses, and anaplasmosis - United States: a practical guide for physicians and other health-care and public health professionals. MMWR Recomm Rep. 2006;55(RR-4):1-27.

174. Krause PJ, Spielman A, Telford SR 3rd, Sikand VK, McKay K, Christianson D, et al. Persistent parasitemia after acute babesiosis. N Engl J Med. 1998;339(3):160-5.

175. Raffalli J, Wormser GP. Persistence of babesiosis for $>2$ years in a patient on rituximab for rheumatoid arthritis. Diagn Microbiol Infect Dis. 2016;85(2):231-2.

176. Vannier E, Krause PJ. Human babesiosis. N Engl J Med. 2012;366(25): 2397-407.

177. Comer JA, Nicholson WL, Olson JG, Childs JE. Serologic testing for human granulocytic ehrlichiosis at a national referral center. J Clin Microbiol. 1999. 37(3):558-64.

178. Centers for Disease C, Prevention. Anaplasmosis and ehrlichiosis - Maine, 2008. MMWR Morb Mortal Wkly Rep. 2009;58(37):1033-6.

179. Schwan TG, Schrumpf ME, Hinnebusch BJ, Anderson DE Jr, Konkel ME. GlpQ: an antigen for serological discrimination between relapsing fever and Lyme borreliosis. J Clin Microbiol. 1996;34(10):2483-92.

180. Wagemakers A, Koetsveld J, Narasimhan S, Wickel M, Deponte K, Bleijlevens B, et al. Variable major proteins as targets for specific antibodies against Borrelia miyamotoi. J Immunol. 2016;196(10):4185-95.
181. Cairns V, Godwin J. Post-Lyme borreliosis syndrome: a meta-analysis of reported symptoms. Int J Epidemiol. 2005;34(6):1340-5.

182. Dersch R, Sommer H, Rauer S, Meerpohl JJ. Prevalence and spectrum of residual symptoms in Lyme neuroborreliosis after pharmacological treatment: a systematic review. J Neurol. 2016;263(1):17-24.

183. Klempner MS, Hu LT, Evans J, Schmid CH, Johnson GM, Trevino RP, et al. Two controlled trials of antibiotic treatment in patients with persistent symptoms and a history of Lyme disease. N Engl J Med. 2001;345(2):85-92.

184. Kaplan RF, Trevino RP, Johnson GM, Levy L, Dornbush R, Hu LT, et al. Cognitive function in post-treatment Lyme disease: do additional antibiotics help? Neurology. 2003;60(12):1916-22.

185. Krupp LB, Hyman LG, Grimson R, Coyle PK, Melville P, Ahnn S, et al. Study and treatment of post Lyme disease (STOP-LD): a randomized double masked clinical trial. Neurology. 2003;60(12):1923-30.

186. Fallon BA, Keilp JG, Corbera KM, Petkova E, Britton CB, Dwyer E, et al. A randomized, placebo-controlled trial of repeated IV antibiotic therapy for Lyme encephalopathy. Neurology. 2008;70(13):992-1003.

187. Berende A, ter Hofstede HJ, Vos FJ, van Middendorp H, Vogelaar ML, Tromp $\mathrm{M}$, et al. Randomized trial of longer-term therapy for symptoms attributed to Lyme disease. N Engl J Med. 2016;374(13):1209-20.

188. Straubinger RK, Summers BA, Chang YF, Appel MJ. Persistence of Borrelia burgdorferi in experimentally infected dogs after antibiotic treatment. J Clin Microbiol. 1997;35(1):111-6.

189. Chang YF, Ku YW, Chang CF, Chang CD, McDonough SP, Divers T, et al. Antibiotic treatment of experimentally Borrelia burgdorferi-infected ponies. Vet Microbiol. 2005:107(3-4):285-94.

190. Parola P, Raoult D. Ticks and tickborne bacterial diseases in humans: an emerging infectious threat. Clin Infect Dis. 2001;32(6):897-928.

191. Piesman J, Eisen L. Prevention of tick-borne diseases. Annu Rev Entomol. 2008:53:323-43.

192. Eisen L, Dolan MC. Evidence for personal protective measures to reduce human contact with blacklegged ticks and for environmentally based control methods to suppress host-seeking blacklegged ticks and reduce infection with Lyme disease spirochetes in tick vectors and rodent reservoirs. J Med Entomol. 2016;53(5):1063-92.

193. Eisen L, Eisen RJ. Critical evaluation of the linkage between tick-based risk measures and the occurrence of Lyme disease cases. J Med Entomol. 2016; 53(5):1050-62

194. Stafford KC III. Tick management handbook. New Haven, USA: Connecticut Agricultural Experiment Station; 2004.

195. Braks M, van Wieren S, Takken W, Sprong H. Ecology and prevention of Lyme borreliosis, Vol. 4. Wageningen: Wageningen Academic Publishers; 2016.

196. Shen AK, Mead PS, Beard CB. The Lyme disease vaccine - a public health perspective. Clin Infect Dis. 2011;52(Suppl. 3):s247-52.

197. Beaujean DJ, Bults M, van Steenbergen JE, Voeten HA. Study on public perceptions and protective behaviors regarding Lyme disease among the general public in the Netherlands: implications for prevention programs. BMC Public Health. 2013;13:225

198. Uspensky I. Ticks as the main target of human tick-borne disease control: Russian practical experience and its lessons. J Vector Ecol. 1999; 24(1):40-53.

199. Sibbald B. Larvicide debate marks start of another West Nile virus summer. CMAJ. 2003:168(11):1455

200. Hubalek Z, Halouzka J, Juricova Z, Sikutova S, Rudolf I. Effect of forest clearing on the abundance of Ixodes ricinus ticks and the prevalence of Borrelia burgdorferi s.l. Med Vet Entomol. 2006;20(2):166-72.

201. Tack W, Madder M, Baeten L, Vanhellemont M, Verheyen K. Shrub clearing adversely affects the abundance of Ixodes ricinus ticks. Exp Appl Acarol. 2013;60(3):411-20

202. Wassermann M, Selzer P, Steidle JLM, Mackenstedt U. Biological control of Ixodes ricinus larvae and nymphs with Metarhizium anisopliae blastospores. Ticks Tick Borne Dis. 2016;7(5):768-71.

203. Deplazes PEJ, Mathis A, von Samson-Himmelstjerna G, Zahner H. Parasitology in Veterinary Medicine. Wageningen: Wageningen Academic Publishers; 2016.

204. Monath TP. Vaccines against diseases transmitted from animals to humans: a one health paradigm. Vaccine. 2013;31(46):5321-38.

205. Kunze U, Bohm G. Tick-borne encephalitis (TBE) and TBE-vaccination in Austria: Update 2014. Wien Med Wochenschr. 2015;165(13-14):290-5.

206. Heinz FX, Stiasny K, Holzmann H, Grgic-Vitek M, Kriz B, Essl A, et al. Vaccination and tick-borne encephalitis, central Europe. Emerg Infect Dis. 2013;19(1):69-76. 
207. Smit R, Postma MJ. Vaccines for tick-borne diseases and cost-effectiveness of vaccination: a public health challenge to reduce the diseases' burden Expert Rev Vaccines. 2016;15(1):5-7.

208. Wressnigg N, Pollabauer EM, Aichinger G, Portsmouth D, Low-Baselli A, Fritsch $S$, et al. Safety and immunogenicity of a novel multivalent OspA vaccine against Lyme borreliosis in healthy adults: a double-blind, randomised, doseescalation phase 1/2 trial. Lancet Infect Dis. 2013;13(8):680-9.

209. Wressnigg N, Barrett PN, Pollabauer EM, O'Rourke M, Portsmouth D, Schwendinger MG, et al. A novel multivalent OspA vaccine against Lyme borreliosis is safe and immunogenic in an adult population previously infected with Borrelia burgdorferi sensu lato. Clin Vaccine Immunol. 2014; 21(11):1490-9.

210. Comstedt P, Schuler W, Meinke A, Lundberg U. The novel Lyme borreliosis vaccine VLA15 shows broad protection against Borrelia species expressing six different OspA serotypes. PLoS One. 2017;12(9):e0184357.

211. Shadick NA, Liang MH, Phillips CB, Fossel K, Kuntz KM. The cost-effectiveness of vaccination against Lyme disease. Arch Intern Med. 2001;161(4):554-61.

212. Lantos PM. Lyme disease vaccination: are we ready to try again? Lancet Infect Dis. 2013;13(8):643-4.

213. Sprong H, Trentelman J, Seemann I, Grubhoffer L, Rego RO, Hajdusek O, et al. ANTIDotE: anti-tick vaccines to prevent tick-borne diseases in Europe. Parasit Vectors. 2014;7:77

214. de la Fuente J, Almazan C, Canales M, de la Lastra JM P, Kocan KM, Willadsen P. A ten-year review of commercial vaccine performance for control of tick infestations on cattle. Anim Health Res Rev. 2007:8(1):23-8.

215. Torina A, Moreno-Cid JA, Blanda V, Fernandez de Mera IG, de la Lastra JM, Scimeca S, et al. Control of tick infestations and pathogen prevalence in cattle and sheep farms vaccinated with the recombinant Subolesin-Major Surface Protein 1a chimeric antigen. Parasit Vectors. 2014;7:10.

216. Valle MR, Mendez L, Valdez M, Redondo M, Espinosa CM, Vargas M, et al. Integrated control of Boophilus microplus ticks in Cuba based on vaccination with the anti-tick vaccine Gavac. Exp Appl Acarol. 2004;34(3-4):375-82.

217. Rasmussen SA, Jamieson DJ, Honein MA, Petersen LR. Zika virus and birth defects - reviewing the evidence for causality. N Engl J Med. 2016;374(20):1981-7.

218. Holzmann H, Aberle SW, Stiasny K, Werner P, Mischak A, Zainer B, et al. Tickborne encephalitis from eating goat cheese in a mountain region of Austria. Emerg Infect Dis. 2009;15(10):1671-3.

219. Margos G, Sing A, Fingerle V. Published data do not support the notion that Borrelia valaisiana is human pathogenic. Infection. 2017;45(4):567-9.

220. Kik M, Nijhof AM, Balk JA, Jongejan F. Babesia sp. EU1 infection in a forest reindeer, the Netherlands. Emerg Infect Dis. 2011;17(5):936-8.

221. Beugnet F, Moreau Y. Babesiosis. Rev Sci Tech. 2015;34(2):627-39.

222. Rozej-Bielicka W, Stypulkowska-Misiurewicz H, Golab E. Human babesiosis. Przegl Epidemiol. 2015;69(3):489-94. 605-8

223. Parola P, Paddock CD, Socolovschi C, Labruna MB, Mediannikov O, Kernif T, et al. Update on tick-borne rickettsioses around the world: a geographic approach. Clin Microbiol Rev. 2013;26(4):657-702.

224. Jahfari S, Coipan EC, Fonville M, van Leeuwen AD, Hengeveld P, Heylen D, et al. Circulation of four Anaplasma phagocytophilum ecotypes in Europe. Parasit Vectors. 2014;7:365.

225. von Loewenich FD, Geissdorfer W, Disque C, Matten J, Schett G, Sakka SG, et al. Detection of "Candidatus Neoehrlichia mikurensis" in two patients with severe febrile illnesses: evidence for a European sequence variant. J Clin Microbiol. 2010;48(7):2630-5.

226. Diniz PP, Schulz BS, Hartmann K, Breitschwerdt EB. "Candidatus Neoehrlichia mikurensis" infection in a dog from Germany. J Clin Microbiol. 2011;49(5):2059-62.

227. Bastian FO, Dash S, Garry RF. Linking chronic wasting disease to scrapie by comparison of Spiroplasma mirum ribosomal DNA sequences. Exp Mol Pathol. 2004;77(1):49-56.

228. Bastian FO, Sanders DE, Forbes WA, Hagius SD, Walker JV, Henk WG, et al. Spiroplasma spp. from transmissible spongiform encephalopathy brains or ticks induce spongiform encephalopathy in ruminants. J Med Microbiol. 2007;56(9):1235-42.

229. Hubalek Z, Rudolf I. Tick-borne viruses in Europe. Parasitol Res. 2012;111(1):9-36.

230. Charrel RN, Attoui H, Butenko AM, Clegg JC, Deubel V, Frolova TV, et al. Tick-borne virus diseases of human interest in Europe. Clin Microbiol Infect. 2004;10(12):1040-55
231. Rushton JO, Lecollinet S, Hubalek Z, Svobodova P, Lussy H, Nowotny N. Tick-borne encephalitis virus in horses, Austria, 2011. Emerg Infect Dis. 2013; 19(4):635-7.

232. Vanmechelen B, Laenen L, Vergote V, Maes P. Grotenhout virus, a novel Nairovirus found in Ixodes ricinus in Belgium. Genome Announc. 2017;5(21): e00288-17.

233. Chastel C. Erve and Eyach: two viruses isolated in France, neuropathogenic for man and widely distributed in western Europe. Bull Acad Natl Med. 1998;182(4):801-9. discussion 9-10

234. Rezelj W, Li P, Chaudhary V, Elliott RM, Jin DY, Brennan B. Differential antagonism of human innate immune responses by tick-borne Phlebovirus nonstructural proteins. mSphere. 2017;2(3):e00234-17.

235. Mariconti M, Epis S, Gaibani P, Dalla Valle C, Sassera D, Tomao P, et al. Humans parasitized by the hard tick Ixodes ricinus are seropositive to Midichloria mitochondrii: is Midichloria a novel pathogen, or just a marker of tick bite? Pathog Glob Health. 2012;106(7):391-6.

236. Hamsikova Z, Silaghi C, Rudolf I, Venclikova K, Mahrikova L, Slovak M, et al. Molecular detection and phylogenetic analysis of Hepatozoon spp. in questing Ixodes ricinus ticks and rodents from Slovakia and Czech Republic. Parasitol Res. 2016;115(10):3897-904.

237. Duron O, Sidi-Boumedine K, Rousset E, Moutailler S, Jourdain E. The importance of ticks in Q fever transmission: what has (and has not) been demonstrated? Trends Parasitol. 2015;31(11):536-52.

238. Nordstoga A, Handeland K, Johansen TB, Iversen L, Gavier-Widen D, Mattsson $\mathrm{R}$, et al. Tularaemia in Norwegian dogs. Vet Microbiol. 2014;173(3-4):318-22.

239. Borde JP, Zange S, Antwerpen MH, Georgi E, von Buttlar $\mathrm{H}$, Kern WW, et al. Five cases of vector-borne Francisella tularensis holarctica infections in southwestern Germany and genetic diversity. Ticks Tick Borne Dis. 2017;8(5):808-12.

240. Regier Y, O Rourke F, Kempf VA. Bartonella spp. - a chance to establish One Health concepts in veterinary and human medicine. Parasit Vectors. 2016;9:261.

241. Eisen L, Gray JS. Chapter 29. Lyme borreliosis prevention strategies: United States versus Europe. In: Braks M, van Wieren S, Takken W, Sprong H, editors. Ecology and prevention of Lyme borreliosis, Vol. 4. Wageningen: Wageningen Academic Publishers; 2016.

\section{Submit your next manuscript to BioMed Central and we will help you at every step:}

- We accept pre-submission inquiries

- Our selector tool helps you to find the most relevant journal

- We provide round the clock customer support

- Convenient online submission

- Thorough peer review

- Inclusion in PubMed and all major indexing services

- Maximum visibility for your research

Submit your manuscript at www.biomedcentral.com/submit
Biomed Central 